\title{
RECENT DEVELOPMENTS IN THE LAW OF EQUITABLE REMEDIES: What CANADA CAN DO FOR YOU
}

\author{
Jeff Berryman*
}

The Supreme Court of Canada has clearly enunciated a distinct equity jurisprudence for Canada. This paper discusses certain aspects of the most recent developments particularly in the area of equitable remedies. The recent "explosion" in the use of Anton Piller decisions is charted, and where appropriate, analogous Commonwealth decisions are discussed. The use of Injunctive remedies is canvassed, as well as specific performance.

\section{INTRODUCTION}

In a recent article written to celebrate the 125th anniversary of the Supreme Court of Canada, Donovan Waters articulated the role of the Supreme Court in developing a distinct style of equity jurisprudence in Canada. ${ }^{1}$ For much of this time the Canadian Court slavishly followed English Courts. As Waters pointed out, it was not until the Court gained complete control of its docket in that the law was amended to eliminate appeals as of right, and it became the final appellate Court in Canada, ${ }^{2}$ that it began to develop its own style of equity jurisprudence. Waters further points out that Canada has been influenced by our close proximity to the United States and, in particular, muchfrom that country has contributed to the developments in the advancement of fiduciary law and the remedial constructive trust. Waters concluded his article with the following observation: ${ }^{3}$

Faculty of Law, University of Windsor, Ontario. Presented at the New Zealand Centre for Public Law, Victoria University of Wellington, Wednesday, 1 August 2001.

1 Donovan Waters "The Reception of Equity in theSupreme Court of Canada (1875-2000)" (2001) 80 Can Bar Rev 620.

2 Waters suggests that this factor is a particularly important one and contrasts it with the plight of the New Zealand Court of Appeal in its attempts to create new fiduciary relationships in Re Goldcorp Exchange Ltd [1995] 1 AC 74 (PC) and [1993] 1 NZLR 257 sub nom Liggett v Kensington (CA). 
The approach to equity in Canada has changed. Also once a relative backwater of rules originating elsewhere, it is now deliberately used as an instrument to turn the flank or fill the silences of accepted common law doctrine and to produce contemporary assessmentsof obligation breach and appropriate response.

In another article I have outlined what I believe has shaped the development of equity jurisprudence in Canada. ${ }^{4}$ With respect to equitable remedies I suggest that Canadian Courts have been required to respond to profound social changes. In particular, the process of capital accretion, the transformation from manufacturing to a service and knowledge economy and increased technological sophistication demand new legal responses. We are entering an era in which the main capital assets of a business are the particular systems and processes of manufacturing rather than the machines themselves. Thus, for example, a car manufacturer still has an assembly plant to produce a physical product. However, its main wealth is intangibles such as: its systems of product design that take a model from concept to market in months rather than years: its managementsystems that assure just in time delivery of parts to reduce inventory: its creative advertising to generate demand: and, its product financing schemes for customers. These assets are amorphous and ephemeral. It is only a collection of legal rights and remedies that give them value. Knowledge workers who now have the capacityto take their skills away with them hold many of these assets rather than being required to bring simple physical and manual dexterity to the factory floor. ${ }^{5}$ The remedies need to protect these new assets are quite different from the traditional manufacturing economies of the past. Another influence in Canada is simply the vastness of its geographical size and its proximity to the United States. This has shaped Canadian beliefs and attitudes towards land and the practices that are adopted for its transfer.

P Drucker"The Age of Social Transformation"The Atlantic Monthly (November 1994) 53. And see also the work of D Foot and D Stoffman Boom Bust \& Echo: How to Profit from the coming Demographic Shift (Macfarlane, Walter \& Ross, 1996) who argues that demographic change drives two thirds of what social change has taken place in the post war era. Boom describes the generation born between 1947 and 1966. Bust, the generation between 1967 and 1979. The decrease in numbers attributed to increasing control over fertility brought aboutby access to birth control. The echo generation is that born between 1980 to 1995. In Canada there are 10 million baby boomers (one third the population, and 6.5 millionechos.) In the US there are 79 million baby boomers and 76 million echos. From these figures Foot demonstrateshow our society has shaped around the needs of the baby boomers; the growth in the housing market to accommodate growing families, and now the depression in the same as there is insufficient population that wants to absorb the housing stock; how the rental market will rise as the echo groupleave home, as will the market for beer; how the dramatic rise in mutual funds and investment services has risen to accommodatethe baby boomers desire to secure their retirement futures; why health and personal security have become consuming passions of the middle aged; and why the leisure industry has taken off, introducing Disney cruise ships, and a Disney World catering for retirees. 
At the start of the new millennium Canada has emerged as a multi-cultural society with a plurality of political, religious, and cultural values, and with a commensurate complex statutory regime supporting competing visions of a virtuous life. Added to this milieu has been the enactment of a Charter of Rights and Freedoms necessitating the rapid creation of an interpretive jurisprudence by the Supreme Court of Canada. Increasingly, Canadians have legalised social issues for resolution. The fashioning and declaration of rights between individuals and between government and individuals have challenged courts. While much of the statutory material provides clear guidance of these rights, it is often left for the courts to fashion remedies from a general exhortation to do what is "just and convenient". Again, the traditional remedies of injunction and declaration have been used in this field.

It is against this background that I offer the following comments on select developments in the law of equitable remedies in Canada. I do not offer them in an attempt to proselytise, but simply to make you aware of what has been happening on the other side of the Pacific.

\section{ANTON PILLER MEET JOHN AND JANE DOE}

It has been close to twenty-five years since the first reported decision on Anton Piller orders. In that time the order has become an important weapon to combat various forms of intellectual property infringement. ${ }^{6}$ However, the order has also been characterised as potentially draconian in effect ${ }^{7}$ and is widely viewed as being at the outer-extreme of judicial orders. ${ }^{8}$ As a consequence much energy has been spent on prescribing the boundaries of the order in a way that protects the legitimate interests of the plaintiff without unduly burdening the defendant. In the United Kingdom, changes to the Copyright, Design and Patents Act (UK)

6 The Anton Piller order is not confined to intellectual property infringement cases. Other uses include:

Preservation of evidence or other records particularly where there is a high risk of destruction as in computer held electronic records.

Enforcement of restraint of trade clauses upon termination of employment where there is the fear that the former employee will has removed confidential client customer lists or other trade secrets.

As a supplement to Mareva injunctions to secure the seizure of assets and their location.

Extra-territorial Anton Piller orders where the plaintiff seeks an injunction to gain access to the defendant's premises located in a different jurisdiction.

As a true supplement to the discovery process. (ed) Remedies: Issues and Perspectives (Scarborough, Ont, Carswell, 1991) 189. 
1988 has given copyright holders a form of prejudgment seizure. In addition, in the new rules of civil procedure, introduced in the Civil Procedure Act (UK) 1997, a statutory search order has been created which enshrines many procedural developments suggested by earlier courts. In particular, the search order requires in all but exceptional cases that an independent supervising solicitor serve an Anton Piller order. The effect of these changes in the United Kingdom has apparently lowered the frequency of this form of order and has probably added significantly to the cost of service.

Anton Piller orders have been fully embraced by all Canadian Courts, but have become a particular specialty of the Federal Courts. Federal Courts in Canada have the exclusive jurisdiction to rule on the registration of matters pertaining to intellectual property, and a shared jurisdiction with Provincial Courts to adjudicate on infringement that does not involve contractual disputes over ownership. In intellectual property disputes plaintiff litigants are drawn to the Federal Court because its orders have national effect. As such there has emerged a sizable Anton Piller jurisprudence in this Court. A particular development has been the creation of a Rolling Order, sometimes referred to as a John and Jane Doe order. A plaintiff faced with numerous incidents of itinerant vendors manufacturing, distributing or retailing infringing merchandise has been able to secure from the Federal Court a blanket order valid for one year, and capable of being renewed, effective over the entire country. Reed J has accurately described the order in the following terms:

The order which is sought is what is known as a "rolling" Anton Piller order. As is obvious from the style of cause, when these orders are obtained from the Court neither the identity nor the address of the persons against whom they will be executed are known. On some occasions, one or two persons may be identified as named defendants but they will have no necessary connection to the Jane and John Does against whom the order will be executed. The known defendants are allegedly infringing intellectual property rights belonging to the plaintiff but in different places, at different times and in different circumstances. These "rolling" orders can be distinguished from defendant-specific Anton Piller orders. While defendant-specific Anton Piller orders may also include Jane and John Doe defendants, in general, the latter will be connected to the named defendants, for example, by being an employee of the defendant or a supplier of the alleged counterfeit goods of the defendant.

The "rolling" orders are executed against street vendors and transient flea market vendors although they are framed in broad enough terms to encompass the search of retail premises, office premises, vehicles, warehouses, as well as residences. They are usually expressed to last a year subject to being renewed. ${ }^{9}$ 
At any one time there may be fifty of these rolling orders effective across the country and they may have up to 800 defendants added to the proceedings. Once the order has been served, and the search and seizure effected, the plaintiff is required to report back to the court at a date specified in the order, and normally within 14 days of execution. At the review, the plaintiff will report on the execution, add the now known defendant to the pleadings by way of amendment, and request an interlocutory order effective until trial. If the defendant has failed to give his or her consent to the search and seizure, the plaintiff will move a separate show cause hearing for contempt of court. In due course the plaintiff will move for judgment, most often given by way of consent or entered in default.

Sensing the novelty of this form of order, the Federal Court has placed a number of additional procedural protections on its granting. They include the following:

(1) The court should be given adequate time to review the motion and supporting documentation. In an action that is being brought against unknown parties and that has been continuingfor some time there is no particular reason for the plaintiffto claim urgency. ${ }^{10}$

(2) The plaintiff should provide evidence of numerous and widespread infringement. The supporting affidavit evidence should show the geographical extent of the infringement so that the order can be drawn to cover a particular area or the entire country. ${ }^{11}$

(3) A rolling order should not authorize execution against an unnamed party occupying residential premises. ${ }^{12}$

(4) Before granting a rolling order it is desirable that the plaintiff provides specific instances of infringement against a named defendant. In this way it is hoped that the validity of the plaintiff's substantive legal claim to hold intellectual property rights will be tested. ${ }^{13}$ This factor is also a concession to the fact that the granting of an Anton Piller order is made in less than ideal conditions, although Canadian courts have accepted that the plaintiff must demonstrate at an extremely strong prima facie level that the plaintiff has a legal right and that it is being infringed. ${ }^{14}$

10 Fila Canada, above.

11 Club Monaco Inc v Woody World Discounts (1999) 2 CPR (4th) 436 (FCTD).

12 Nike Canada Ltdv Jane Doe (1999) 2 CPR(4th) 501 (FCTD). The residential premisesmust be actual occupied as a residence.

13 Columbia Pictures Industry Ltd v John and Jane Doe (2 October 2000)T-1270-00 (FCTD).

$14 \quad$ Nintendo of America Inc v Coinex Video Games InC [1983] 2 FC 189 (CA), and Pulse Microsystems Ltd $v$ SafeSoft Systems Inc (1996) 134 DLR (4th) 701 (Manitoba CA). 
Canada has not been alone in advancing a broad Anton Piller order against unknown defendants. In the United Kingdom there is at least one reported decision in which the courthas come close to awarding a rolling type order. In EMI Records Ltd $v$ Kudhail ${ }^{15}$ the plaintiff successfully gained an interlocutory injunction against the named defendant and "all other persons engaged in the trade of selling tapes bearing the trade-name 'Oak Records'". This order was granted on the basis that the named defendant was a representative of the class of copyright and trade-mark infringers. The court saw in the individuals sufficient common interest and found (inferred) that they were linked in some secret organization for the distribution of pirated material. In this sense the action was a representative class action. ${ }^{16}$ In Canada the representative defendant action has been rejected in that there is little way for the court to be assured that the defendant will mount a vigorous defence for the class. ${ }^{17}$

In both New Zealand and Australia, in cases involving the same plaintiff, a form of rolling order has been granted. In both Tony Blain Pty Ltd $v$ Splain $^{18}$ and Tony Blain Pty Ltd $v$ Jamison ${ }^{19}$ the plaintiff sought an order against named and unnamed defendants to restrain the sale of pirated copyright material outside specified concert venues when Paul McCartney and Metallica were performing. The Australian Federal Court order closely follows the Kudhail case and is clearly decided on the basis that the named defendants are representatives of the wider class. However, thejudgment differs in two important respects. The plaintiff is allowed to seize infringing merchandise, and must provide independent legal advice on the spot to the persons served with the order.

In the New Zealand case, the judgment does not make the named defendants representatives of the class, but is clearly aimed at unnamed persons who happen to be at the venue sites and dealing in infringing merchandise. In this sense the order is against persons unknown who are bound to obey once served with the order. The order does allow seizure (required delivery up of infringing merchandise) and requires the defendant to provide his or her full name and place of abode that has to be verified by the production of some documentary evidence. This decision has been severely criticised in a subsequent decision of the Victorian Court of Appeal. In a

EMI Records Ltd v Kudhail [1985] FSR 36 (CA).

16 It is also interesting to note that the order did not allow either search or seizure, but merely required the served defendant to stop dealing in pirated merchandise. See the article by D Barron "Roving Anton Piller Orders: Yet to Be Born, Dead, or Alive" [1996] 4 European Intellectual Property Review 183, who notes that this type of order has been termed a "Doorstep Piller".

17 Montres Rolex SA v Balshin [1993] 1 FC 236 (CA).

18 Tony Blain Pty Ltd $v$ Splain [1993] 3 NZLR 185 (HC).

19 Tony Blain Pty Ltd v Jamison (1993) 41 FCR 414 (FCTD). 
decision dealing with the issue of whether an interlocutory injunction can be made against unnamed parties the Court said of Anderson J's judgment that: ${ }^{20}$

The order ${ }^{\circ}$ thus had the novel feature - which would have appealed to Lewis Carroll - that it became binding upon a person only because that person was already in breach of it.

The order of Anderson J, was, as we have said, directed to the world at large. The existing law and procedure may be inadequate to deal with the reprehensible activities of these intellectual property bootleggers, but, with respect, we cannot accept that an injunction can be granted against all the world.

Whether an injunction can be granted against all the world is taken up in the second part of this paper, however, the experience in other jurisdiction as exemplified by these cases clearly demonstrates a need for a wider form of Anton Piller relief.

Fitting a rolling order within the present tests used to determine whether an Anton Piller order should be granted raises particular problems. The three-part test established by the English courts is applied in Canada.

(1) Plaintiff must show an extremely strong prima facie case.

(2) The damage, potential or actual, must be very serious for the applicant.

(3) There must be clear and convincing evidence that the defendant has in her possession incriminating documents or things and a real possibility that they may destroy such material before an application inter parte could be made. ${ }^{21}$

With respect to the first part, the accessibility threshold, while it is relatively easy for a plaintiff to establish an extremely strong prima facie claim to hold intellectual property based on some form of statutory registration scheme, it is more problematic to prove that an unknown defendant is actually infringingthose rights. CanadianCourts have accepted affidavit evidence acquired by a plaintiff's private investigatorsthat demonstrate widespread infringementat flea markets, by itinerant vendors, and, more recently from small variety (dairy) stores. This evidence is more generic than defendant specific. Once sufficient evidence of widespread infringement is proven, a rolling order is justified.

With respect to the second test, rolling orders raises no new features. Courts have accepted that this part of the test has been met where the plaintiff can establish serious loss by demonstrating the degree of disruption such activity will cause the plaintiff's business (ie loss 
of goodwill, clients or trade reputation) or, by a monetary quantification of damages (ie the likely loss of sales should the defendant be allowed to continue selling infringing material) which, in the plaintiff's particular circumstances is seen as being "serious". ${ }^{22}$

The third test has been described as the "crucial element of proof"23 and at the "crux" of obtaining Anton Piller relief. ${ }^{24}$ Despite the self-confessed centrality of this part Canadian courts have readily admitted that the evidence adduced by plaintiff seldom reaches an exacting standard. In Adobe Systems Inc v KLJ Computer Solutions Inc Richard ACJ summarized the court's approach: ${ }^{25}$

It is difficult to prove with tangible evidence that an infringer has a history of destroying evidence or will dispose of important evidence. Applicants have therefore focussed on the dishonest character of the infringer and the easily disposable nature of the infringing articles to invite the Court to draw an inference that evidence will disappear if notice is given.

In applying this test Canadian courts appear to have focussed upon three criteria; easy of removal and disposal of goods, ${ }^{26}$ the transient nature of the defendant and his or her business, ${ }^{27}$ and a plaintiff's prior experience in dealing with infringers generally. ${ }^{28}$

Nintendo of America Incv Coinex Video Games Inc, and Adobe Systems Inc v KLJComputer Solutions Inc [1999] 3 FC 621. 71 CPR (3d) 37, 44 (Alta QB) Paperny J:

It is almost impossible for an applicant to produce direct proof that a defendant will destroy the material. Generally, courts have inferred a risk of destruction when it is shown that the defendant has been acting dishonestly, for example where matter has been acquired in suspicious circumstances, or where the defendant has knowingly violated the applicant's rights.

Cullom Machine Tool \& Die Inc v Bruce Tile Inc (1990), 34 CPR (3d) 296 (FCTD) and Nintendo of America Inc v Coinex Video Games InC [1983] 2 FC 189 (CA), and Pulse Microsystems Ltd v SafeSoft Systems Inc (1996) 134 DLR $\left(4^{\text {th }}\right) 701$ (Manitoba CA). But, contrast with Pulse Microsystems Ltd $v$ SafeSoft Systems Inc, ease of destruction of computer records insufficient grounds tojustify Anton Piller order. Star Distribution Group Inc, above, Lufty ACJ.

Titan Sports Inc v Mansion House (Toronto) Ltd [1990] 1 FC 448, and Nike Canada Ltd v Jane Doe (1999), 2 CPR (4th) 501 (FCTD). But contrast with Chin-Chin Communications Corporation v Chinese Vido Centre Ltd (1983), 70 CPR (2d) 184 (FCTD) evidence of other defendants in similar cases dismissed as having any relevance of likelihood of the propensity of the defendant to remove or destroy evidence. 
Rolling orders are an evolving jurisdiction for the federal Court. Unfortunately, there has been little direction provided by senior appellate courts. However, trial courts have advanced, in an uncoordinated way, procedural safeguards on the execution and prosecution of these orders. The Federal Court now has a quite highly structured approach to review the execution of these orders. The function of the review process is twofold. First, it is to review the execution of the order and to ensure that the applicant dischargedall the obligations associated with the order. "This affords the Court the opportunity to ensure that the moving party has discharged its obligation to ensure that any order which is obtained is fairly executed". ${ }^{29}$ Second, the court is determining what orders are appropriate in light of the evidence now properly introduced by the applicant. In this sense court reviewing an Anton Piller order is not conducting an appeal but is acting de novo and must consider, on the evidence and legal arguments now before it, what orders are appropriate. ${ }^{30}$

The wording of the standard Anton Piller order used by the Federal Court provides that it can be set aside or varied at any time by the court on a review. This can occur each time the applicant seeks to add a new defendant to the action after their identity has become known during execution of the order. The setting aside or variation of the order at this time does not operate retroactively, although the court can so order under Federal Court Rule 399. ${ }^{31}$ In the case of a rolling Anton Piller order, where the applicant is likely to execute the order on a significant number of parties and, therefore, the Federal Court will have numerous occasions to review the initial order, there is important value attached to judicial comity and the confirmation orders of previous Courts. However, where the Anton Piller order has not be subject to adversarial litigation, and therefore, the Court is at a disadvantage with respect to evidence and legal arguments which may have cast doubt of the applicant's initial motion, the court should respond to any new information which it may receive when consideringthe motion then currently before the Court, and for which it can be assumed that the earlier judge was not cognisant at the time of granting the initial order. ${ }^{32}$

The development of rolling Anton Piller orders has not attracted a great deal of attention by commentators as it is still in its embryonic form. ${ }^{33}$ The simple truth is that few defendants

29 Adobe Systems Inc, above n 23, Richard ACJ.

30 Adobe Systems Inc, above n 29; Top Star Distribution Group Inc above n 24; WIC Premium Television v Levin (28 April 1999) FCJ No 652 (FCTD); Pulse Microsystems Ltdv SafeSoft Systems Inc 1996) 134 $\operatorname{DLR}\left(4^{\text {th }}\right) 701$ (Manitoba CA).

$31 \quad$ Fila Canada Inc $v$ Jane Doe (1996) 68 CPR (3d) 1 (FCTD).

$32 \quad H a v a n a$ House Cigar $\mathcal{E}$ Tobacco Merchants Ltd $v$ Jane Doe (1999) 1 CPR (4 $\left.4^{\text {th }}\right) 521$ (FCTD), and Nike Canada Ltd v Jane Doe (1999), 2 CPR (4th) 501 (FCTD).

33 See D Bales "The Anton Piller Order: The Monster that Even Dr Frankenstein can no longer Control" (1999) 57 The Advocate 401. 
mount a vigorous defence to the injunction. Whether this is due to a lack of financial resources, or that the defendants genuinely accept that they are guilty of infringing plaintiffs' rights, is difficult to discern. For the Federal Court, which has jurisdiction over intellectual property matters and a national reach, the advancement of rolling orders is a natural fit. The Court has been placed in a quandary. During the last decade the Federal government has systematically revised most of Canada's intellectual property statutes. At no time has the legislature sought to change the direction the Federal Court has taken, nor has it seen the need to specifically legislate in this area as happened in the United Kingdom. The two most recent remedial measures introduced by the Federal government have been the adoption of statutory damages, modelled on US experience, and the creation of a "wide injunction" - one that would appear to allow the plaintiff to seek interlocutory relief to restrain use, and seize infringing works, of other peoples' copyright in conjunctionwith the plaintiff's own action against a defendant - for copyright violation. If use is a measure of need, then there is an obvious desire on behalf of the plaintiffs' bar to have rolling orders. The anecdotal evidence is that counterfeiters and infringers are highly organised. Unless Anton Piller "raids" are coordinated the execution against one flea-market vendor will quickly be communicated to all others in the geographical vicinity resulting in a rapid concealment of the counterfeit goods. A particular concern in Canada is the piracy of satellite broadcast signals. Small retailers will sell many of the decoding devices, however, the goods are not held on the premises and the sale is effected only by agreeing to meet on a certain street corner.

The infringement of intellectual property is widespread; yet, its consequences are largely economic. Although infringement constitutes criminal activity, it does not attract the public's attention nor police and prosecutorialresources. [As an aside, it is interesting to speculate that the protection of valuable assets, which are creatures of the new economy, is left in private hands through the use of a form of privatised criminal law; Anton Piller constituting the search warrant, and statutory damages the fine.] The Federal Court has opted to gap-fill this legislative lacuna.

\section{INJUNCTIONS - THE ABILITY TO BINDNON-PARTIES - MACMILLAN BLOEDEL V SIMPSON ${ }^{34}$}

It is an axiom of our common law that an injunction cannot be made against the world at large, one that is contra mundum. The corollary of this principle is that only a party to an injunctive order is bound by it. At its root this rule embodies the principle that an individual has a right to be heard before being condemned, audi alteram partem. Historically, and with respect to injunctions, the rule is said to be derived from the judgment of Lord Eldon in Iveson

34 I pursue this issue in a longer article within the context of Canadian jurisprudence, see "Injunctions - The Ability to Bind Non-Parties" (2002) Can Bar Rev (forthcoming). 
$v$ Harris. ${ }^{35}$ It is also supported on the grounds that equity acts only in personam, an injunction made against the world at large takes on the indicia of an in rem order and thus exceeds equity's traditional jurisdictional boundaries. Historically, the reification of the in personam jurisdiction was an important distinction between judicial and legislative function as well as between common law and chancery courts.

Despite the long pedigree of this axiom litigants have persisted in trying to bind non-parties to injunctive orders. Actions against industrial picketers ${ }^{36}$ or environmental protesters ${ }^{37}$ who wish to disrupt and halt the plaintiff's commercial activities, and plaintiffs seeking to prevent the widespread disclosure of confidential material, ${ }^{38}$ are but two examples. In fact, the rolling Anton Piller order just discussed, has many characteristics of an order made against all the world. Judicial response to these overtures has usually resulted in the denial of direct relief aimed at binding unknown parties. However, what has been denied directly, has been granted indirectly, by holding that a non-party who fails to obey an injunction may be guilty of contempt of court for aiding or abetting, inter-meddling, or otherwise interfering with the administration of justice. Jurisdictional differences occur over what constitutes interference with the administration of justice. As a result of the decision in MacMillan Bloedel $v$ Simpson the Supreme Court of Canada has adopted a very liberal approach to defining those words. ${ }^{39}$

The judgement of Lindley LJ in Seaward $v$ Paterson ${ }^{40}$ is widely regarded as providing the formulation of a non-party's liability for contempt. The plaintiff had successfully gained an injunction against the defendant Paterson, his agents and servants, requiring the defendant to refrain from creating a disturbance in premises abutting the plaintiff's premises. The defendant continued to run boxing fights in violation of the injunction. The plaintiff then brought committal proceedings against the defendant, his servant Sheppard, who had acted as "master of ceremonies", and Murray, a spectator and collaborator in running the boxing bouts. The trial judge had found all three guilty of contempt. The defendant was guilty of direct breach of the injunction, while Sheppard and Murray were guilty of aiding and abetting the defendant. Murray appealed. The judges of the Court of Appeal were unanimous in seeing no merit in the appeal. Lindley LJ: ${ }^{41}$

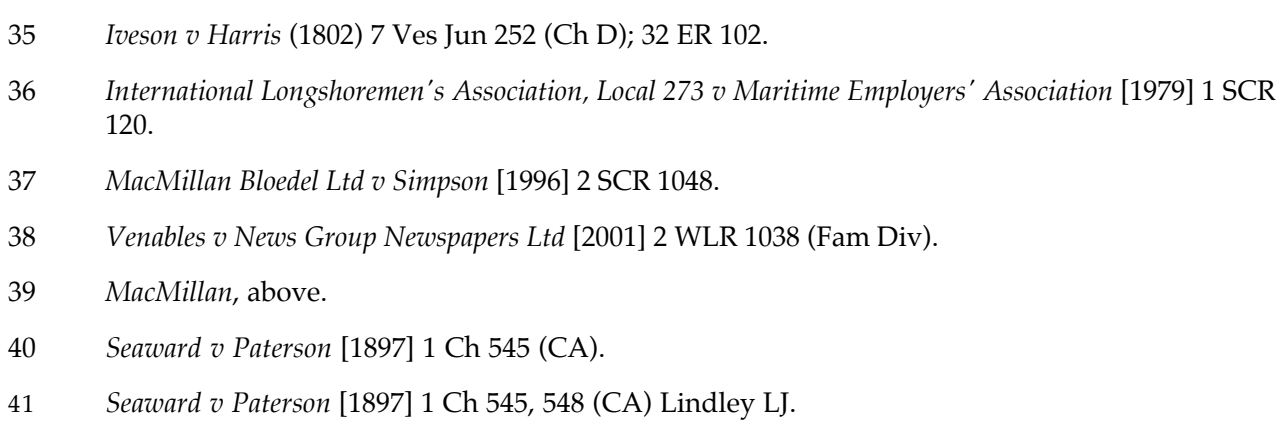


A motion to commit a man for breach of an injunction, which is technically wrong unless he is bound by the injunction, is one thing; and a motion to commit a man for contempt of Court, not because he is bound by the injunction by being a party to the cause, but because he is conducting himself so as to obstruct the course of justice, is another and a totally different thing. The difference is very marked. In the one case the party who is bound by the injunction isproceeded against for the purpose of enforcing the order of the Court for the benefit of the person who got it. In the other case, the Court will not allow its process to be set at naught and treated with contempt.... The distinction between the two kinds of contempt is perfectly well known, although in some cases there may be a little difficulty in saying on which side of the line the case falls.

While Lindley LJ alludes to the liability of a non-party for contempt for obstructing the course of justice, this form of liability was rarely litigated in the United Kingdom although, in contrast, frequent reference was made to Lord Eldon's judgment in Iveson v Harris. It was not until A-G v Newspaper Publishing Plc $c^{42}$ that the House of Lords clearly confronted the liability of a non-party for contempton the basis of interfering and impeding the administration of justice. This case was one of many dealing with the publicationby Mr Peter Wright, a former British security service employee, of his book Spycatcher. The action was brought by the Attorney-General to restrain a number of newspapers from publishing serialisations of the book in the United Kingdom. The question before the court was whether non-parties who had knowledge of an injunction issued against other newspapers, and which enjoined them from publishing parts of Mr Wright's book until such time as the issue of the crown's claim for breach of confidentiality had been determined, were guilty of contempt of court when they subsequently published a serialisation of the book.

The appellants won in the trial court, although this was reversed on appeal. Before the House of Lords the appellants vigorously argued that a non-party could only be held in contempt of court where they had knowingly aided and abetted the named defendant in breaching the order and that there was no other contempt jurisdiction against non-parties. Thus, the court confronted the precise bounds of the contempt jurisdiction and what was covered in the notion of "impeding or prejudicing the administration of justice by the court" in proceedings brought between the named litigants. The appellants conceded that they were aware of the injunction, and that they had intended by their publication to impede the administration of justice. The effect of publication was to destroy the subject matter of the litigation and to render the Attorney-General's claim for confidentiality of the Wright information pointless. The Attorney-General had not alleged any linkage between the named defendants and the appellants who were competitors, as such, there was no issue of aiding and abetting. Thus, the appellants argued that they had not committed the actus reus of the contempt 
in that there was no contempt for impeding the administrationof justice by a non-party. On this question the Lords were unanimous that the appellants were wrong and were indeed guilty of contempt.

All the Lords' judgments follow a similar pattern of reasoning. First, they recognise in the earlier English authorities a distinction between contempt for breaching an injunction as a named party and contempt by a non-party for aiding and abetting. Second, they recognise that in earlier decisions the Courts found in contempt those who knowingly interfere with the administration of justice. However, there was little unanimity on when interference occurs. Lord Brandon's approach would tend to look only at results. If the net effect of the non-party's conduct is to do what the named party was enjoined from doing, then the non-party is guilty of contempt regardlessof any legitimate right he or she may have for carrying out the very conduct that named defendant cannot. Lord Jauncey was more circumspect and acknowledged that there: 43

may be cases where the perfectly legitimate pursuit of a purposeby a strangerhas the incidental result in frustrating an order. It does not inevitably follow that such a pursuit will constitute a contempt.

He also suggested that it was likely only in a limited number of cases: ${ }^{44}$

that independent action by a third party will have the effect of interfering with the operation of an order to which he is not a party.

Lord Oliver saw little value in cataloguing hypothetical circumstances that showed when the line of interference in the administration of justice was crossed. Rather, he signalled the importance that the activities of the non-party must ${ }^{45}$

frustrate, thwart, or subvert the purpose of the court's order and thereby interferes with the due administration of justice in the particular action [emphasis in the original].

"Purpose" here refers to the Court's objective in seeking to administer justice between the litigants, which, on the facts before the court, was to preserve in the interim the confidentiality of the Crown's information. However, Lord Oliver did go on to deal with some of the particular objections the appellants had raised. First, he acknowledged that a stranger to litigation could well be advancing his or her own interest but, nevertheless, destroy the substrata of the action between the named litigants; yet, this did not necessarily constitute the

43 Attorney-General v Newspaper Publishing Plc, above, 231 Lord Jauncey.

$44 \quad$ Attorney-General v Newspaper Publishing Plc, above, 231, Lord Jauncey.

45 Attorney-General v Newspaper Publishing Plc, above, 233, Lord Jauncey; Attorney-General v Leveller Magazine Ltd [1979] AC 440 (HL). 
actus reus of contempt. Second, the appellant argued that the focus on "purpose", as defined above, requires the non-party to be able to readily determine the ambit of the court's order. An order, which tells a named party to refrain from a certain act, achieves that purpose when the named party complies. To require something of non-parties invites uncertainty, and, in matters of criminal liability for contempt, uncertainty should not be permitted. Lord Oliver saw merit in this argument to the extent that a non-party could not readily determine the purpose of the court in making the order. However, in that case, he opined, that the non-party would escape liability because the necessary mens rea would not be proved. ${ }^{46}$

...[F]or an intention to frustrate the purpose of the court would be difficult to establish if the purpose itself was not either known or obvious.

Third, the appellant argued that a non-party who is held in contemptfor interference with the administration of justice is deprived of any opportunity to arguebefore the court that he or she is free to carry out the enjoined conduct because they are not litigants in any proceeding. Lord Oliver registered disquiet over this particular aspect of the contempt jurisdiction but thought that the non-party, in the facts before the court, was largely author of his own misfortune. That is, the appellant could well have come to court prior to publishing the serialisation of Wright's book and sought directions as to whether what it intended to do violated the court's order. Lord Oliver analogised to the frequent actions of third-party banks that seek court directions to determine what is required to comply with a Mareva injunction.

As analysed in A-G v Newspaper Publishers Plc the constituent elements of a contempt charge brought against a non-party requires both mens rea and actus reus. Actus reus requires that the non-party has done an act that, if performed by the named party would constitute a contempt of the Court's order by that party, and which does interfere or impede the administration of justice in that it frustrates or renders futile the main purpose for which the court granted the injunction in the initial proceedings. In a subsequent case before the Court of Appeal, A-G $v$ Newspapers Publishing $P l c_{1}^{47}$ the Court indicated that the adverse effect on the administration of justice had to be "significant" and that a "trivial or technical" breach could be ignored. With respect to the mens rea, that being conceded by the appellant in the House of Lords, their Lords had little to say, although, Lords Brandon and Jauncey both indicated it would be necessary to prove that the non-party "knowingly" intended to interfere or impede the 
administration of justice. In the Court of Appeal, where this issue had been disputed, Lord Donaldson MR stated on the question of what type of intent was required: ${ }^{48}$

....what is contemplated....is the power of the court to commit for contempt where the conduct complained of is specifically intended to impede or prejudice the administration of justice. Such an intent need not be expressly avowed or admitted, but can be inferred from all the circumstances, including the foreseeability of the consequences of the conduct. Nor need it be the sole intention of the contemnor. An intent is to be distinguished from motive or desire.

The mens rea requirement for this form of contempt is different from the requirement for contempt by a named party in disobeying the injunction. In the latter, all that is required is that the defendant acted intentionally to breach the court's order and liability is then strict. ${ }^{49}$

Recently, in a case that is remarkably similar to the Spycatcher saga, the English Court of Appeal further expanded on what constitutes the actus reus and mens rea. In Steenv A-G ${ }^{50}$ the appellant, editor of Punch magazine, published a series of columns written by David Shayler, a former employee of the English Secret Service. Prior to the publication of the columns the Attorney-General had successfully obtained an interlocutory injunction restraining both Shayler and Associated Newspapers from publishing any material of a confidential nature which Shayler had acquired while in the employ of the Secret Service. The columns published in Punch contained previously published material and also new material, which up until its publication had been confidential. The Attorney-Generalbroughtcontempt proceedingsagainst Steen on the basis that the publication of this material impeded and interfered with the administration of justice. Steen, who was unsuccessful in the trial court, defended against the charge on the basis that the Attorney-Generalhad failed to prove that he had the requisite actus reus or mens rea.

After an extensive review of the Spycatcher cases the Court of Appeal held that the requisite actus reus was met when the Attorney-General proved that Steen had published the columns so as to defeat the purpose of the injunction which was; "to preserve until trial the confidentiality

Attorney-General v Newspapers Publishing Plc [1988] 1 Ch333, 374 (CA) Lord Donaldson MR. Lord Donaldson MR's approach was itself endorsed in Attorney-General v Newspapers Publishing Plc, above, Lord Bingham CJ.

See Jeffrey Miller The Law of Contempt in Canada (3rd ed, Scarborough, (Ontario), 2000) 4.52. The spectre of contempt for impeding or interfering with the administration of justice has created the possibility that a party could be held liable for contempt in advance of any order being granted on the basis that the non-party's actions have prejudiced the rights of a named party in potential litigation and have thus impeded the administration of justice. This was argued in Harrow London Borough Councilv Johnstone [1997] 1 WLR 429(HL) where the Court rejected such a submission. granted [2001] 1 WLR 2111 (CA). 
of material whose disclosure arguably posed a risk of damaging national security". ${ }^{1}$ Turning to the mens rea, a majority of the court held that it had not been met because the AttorneyGeneral had failed to prove that the appellant had the requisite knowledge "that publication would interfere with the course of justice by defeating the purpose underlying the injunction". The evidence showed that Steen was anxious not to publish material that would impact upon national security. He argued, and the majority accepted, that the inclusion of a proviso in the original injunction, which had purported to exclude from the injunction's ambit subsequent material in which the Attorney-General made a statement indicating that no confidentiality would be claimed, made the purpose of the order difficult to discern. In particular, was the order's purpose to restrain any and all statements from Shayler, or, only those that threatened national security? In addition, Steen had corresponded with the Treasury Solicitor, the appropriate government officer, to determine the parameters of the injunction and whether the material he was about to publish was a threat to national security. The correspondence with the Treasury Solicitor never clarified these areas and, with respect to the particular column that had precipitated the contemptcharge, the appellant had reasonable grounds to believe that the Treasury Solicitor had delayed in replying so as to save the government from embarrassment. It was not sufficient for the Attorney-General to prove that Steen alone had knowledge of the injunction and intended to publish to satisfy the mens rea requirement. This judgment is further evidence of just how narrow the jurisdiction is on bringing suits for contempt against third parties based on impeding or interfering with the administration of justice.

The English approach to the liability of a non-party to obey a court order has witnessed a slow incremental growth in the type of conduct that will make a non-party liable for contempt. The United Kingdom courts have consistently affirmed the position that only parties to an action are bound by the court's order. The extension of contemptbeyond aiders, abettors and inter-meddlers has been cautiously approved where the non-party intentionally sets out to impede or interfere with the administration of justice. Unfortunately it is difficult to give much precision as to when the actions of a non-party will impede the administration of justice. The vast majority of United Kingdom cases appear to arise from the protection of confidentiality or theidentity of witnesses. ${ }^{52}$ In these cases it is relativelyeasy to seehow any subsequent violation of a court order will impede the administration of justice where it will destroy the very substrata of the action and the rights protected by the court in upholding the

51 The purpose of the injunction is described as including the preservationof confidentiality whose disclosure poses a risk of damaging national security, which recognises the different approach to confidentiality applied to government as against a citizen. The government has no particular right to confidencebased on privacy but can only argue confidentialityif it advances some public interest such as the maintenance of national security. 
confidentiality or secrecy. Even in these cases, proving the necessary mens rea may be very problematic. Nevertheless, there have been a number of instances where United Kingdom Courts have developed a true exception to the notion that only parties to an action can be bound by a court's order and have created an injunction that issues against the world at large, or contra mundum. The instances where this type of order has been made are varied, however, they have in common the element that the enjoined action, usually that of the press, if it went ahead unabated, would reveal the identity or current location of the plaintiff, and to the plaintiff's alleged detriment. For example, in Re X (A Minor) (Wardship: Injunction) ${ }^{53}$ Mary Bell was found guilty of manslaughter of two boys when she was aged eleven. She was later released as part of her rehabilitationand had given birth to a child after her release. The News of the World newspaper became aware of Mary Bell's circumstances and proposed to run a feature story. The local council then brought an action to seek an order preventing publication of material which might lead to revealing the name Mary Bell now used and thus to identifying her daughter who had been made a ward of the court. Balcombe J granted the injunction pursuant to the court's inherent jurisdiction to act in the best interest of wards of the court. ${ }^{54}$ (The injunctionwas granted to protect Mary Bell's child and not Mary Bell herself.) However, the injunction would only be effective against those who had notice of it. This jurisdiction to award an injunction against all the world to protect wards and others who fall within the court's inherent parens patriae jurisdiction has been followed in numerous other cases.

A more novel application has recently arisen in Venables $v$ News Group Newspapers Ltd ${ }^{55}$ In 1993 the two claimants had killed a toddler. Following their trials they were placed in detention homes runby a local authority. At the time of the trial an injunctionhad been granted preventing the publication of information about the claimants following their trial so that they would be given an opportunity to rehabilitate themselves free from constant media attention. Upon attaining the age of eighteen (the age of majority) the claimants sought extension of the publication ban issued in 1993. The claimants were motivated to make this request after a number of newspapers and media groups applied to have clarification of the original injunction once the claimants gained the age of majority. In particular, the claimants wanted the news media to be restrained from publishing any current pictures, the location of their current detention homes, and details about their future placements in the community. This case differed from that of a minor or ward of the court in that the material sought to be enjoined related to the period when the claimants were of the age of majority. The claimants, although parties in

$53 \operatorname{Re} X$ (A Minor) (Wardship: Injunction [1984] 1 WLR 1422 (Fam Div).

54 Balcombe J (as he then was) doubted whether he had jurisdiction to grant such an order beyond a person who was a ward of the court. In Attorney-General v Newspaper Publishing Plc [1988] 1 Ch 333 (CA) Lord Donaldson MR, Lord Donaldson MR doubted the validity of Balcombe J's judgment, however, Balcombe LJ affirmed the correctness of his earlier ruling. 
unique circumstance, were not appreciably different from other infamous people who are subject to media attention. It is for this reason that they argued they were entitled to protect confidential information. The defendant then argued that under the appropriate common law doctrines of confidentiality, the Court was required to consider the public interest in allowing disclosure and that since the enactment of the Human Rights Act (UK) 1998 and European Convention on Human Rights, the Court was required to give press freedom paramount importance. To this submission the claimants argued that in balancing the publicinterest, they were also entitled to protection under the Human Rights Act and Convention where the evidence showed that publication of the material, and thus identification of the claimants, would result in a real risk of their being harmed by those who wished to avenge the murder of the toddler. Butler-Sloss P accepted that the law of confidentiality, in light of the direction of the human rights legislation, could cover the unique circumstances of the claimants and that the court had jurisdiction to grant an injunction. The right to press freedom of expression had to be construed consistently with other rights in the legislation, and, in particular, the claimants' rights to life, prohibition of torture, and respect for private and family life (articles 2, 3, \& 8 of the European Convention). Turning to the scope of the injunction,Butler-Sloss P recognised that an order made against the lone defendant would be ineffective if other newspapers were then free to publish what the News of the World had been prevented. Although an order made against a named defendant could give rise to contempt proceedings if subsequent actions of a non-party could be found to be an interference with the administration of justice, Butler-Sloss P believed it was inappropriate to do through the back door what she could not do through the front door. Relying upon a broad requirement to act in a manner compatible with the European Convention, she declined to follow the dictum of Lord Eldon in Iveson $v$ Harris and granted the injunction against the world at large. The terms of the injunction were to ensure that any information that would lead to the future identification and location of the claimants was not published, including photographs, and interviews with co-detainees and care-givers. Information on the workings of the secure units where they had been detained before being paroled could be published after a period of twelve months had elapsed provided it would not lead to the identification and current location of the claimants. The injunction was to operate for the future, presumably for the natural life of the claimants, and it prohibited all publication by any form of media. Anticipating the fact that because the injunction could only be effective in England and Wales, and that material that is once placed in the public domain can nolonger be considered confidential, Butler-Sloss $\mathrm{P}$ also prohibited the wider circulation of material that may have entered the public domain through the Internet or other foreign media outlets.

In the English context the effect of making the order against the world at large will subject a non-party who violates the terms of the injunction guilty of civil contempt rather than criminal contempt, the appropriate charge when the non-party interferes or impedes the 
administration of justice. ${ }^{56}$ This would effectively alter the mens rea requirement, the former requiring an intentional act to breach the order that is not "casual and accidental or unintentional". 57 The latter, requires proof of an actual intent to impede or interfere with the administration of justice. However, in both cases actual knowledge of the injunction would still be a prerequisite to any committal proceeding of a non-party for contempt.

In contrast to the United Kingdom developments, Canadian Courts have had a propensity to find non-partiesin contempt of court. Canadian Courts have, from an early stage, recognised that it is appropriate to specifically address in the style of cause that the injunction enjoins "anyone having knowledge of the order". This approach stems from the fact that most disputes of this nature have arisen in the context of union picketing where the plaintiffemployer has had difficulty identify all the picketers and has asked for the injunction to enjoin "trade-union officers, members and servants". This terminology has been endorsed by the Supreme Court of Canada on the basis that: ${ }^{58}$

\footnotetext{
...it makes the impact and sense of the order clear to all those likely to be affected thereby and, in any event, such wording can hardly be said to harm any of the persons in law affected by the order.
}

The earlier Canadian cases also seem tohave drawn distinctions between aid and abetting, inter-meddling, and interfering with the administration of justice. The cases in which a nonparty has been found guilty of contempt for aiding and abetting are cases where the non-party has acted in collusion with the named party to achieve a single objective. ${ }^{59}$ Where the nonparty has been found to be inter-meddling, the non-party's intent and objective in participating is not the same as the named party, yet the non-party is aware that his or her actions will further the named party's goal in some respect. ${ }^{60}$ In the case of interfering with the

56 Jeffrey Miller The Law of Contempt (3rd ed, Scarborough, (Ontario), 2000) paras 4.52 and 14.61. Note that in Scott $v$ Scott [1913] AC 417, 458 (HL) Lord Atkinson described as absurd the notion that a named person who violates an injunction is liable only for civil contempt, whereas, a nonparty who impedes the administration of justice is guilty of criminal contempt.

Heatons Transport (St Helens) Ltd v Transport and General Workers' Union [1973] AC 15 (HL), and see Miller, above, 14.51.

International Longshoremen's Association, Local 273 v Maritime Employers' Association International Longshoremen's Association, Local 273 v Maritime Employers' Association [1979] 1 SCR 120 Estey J. But, note the differing opinion of the Manitoba Court of Appeal in Griffin Steel Foundries Ltd $v$ Canadian Association of Industrial, Mechanical and Allied Workers (1977) 80 DLR (3d) 634. (SC \& CA).

60 See, for example, Re Tilco Plastics Ltd v Skurjat (1966) 57 DLR (2d) 596 (Ont HC), appeal to Court of Appeal dismissed and leave to Supreme Court of Canada refused (1967) 61 DLR (2d) 664 (Ont $\mathrm{HC})$. 
administration of justice, the non-party's actions have the same effect as the enjoined conduct regardless of how that may advance the interests of the named party. In this sense, even totally independent action by the non-party will give rise to contempt if it violates the terms of the injunction. ${ }^{61}$ In this position, the primary function of the contempt proceeding is to maintain authority and respect for the court in the face of defiance. However, theCourts have expressed ambivalence on whether the defiance has to be "public" so as to amount to an "open" and very public display of defiance, or whether merely participating in carrying out the enjoined activity is enough to comprise defiance of the court's authority. ${ }^{62}$

Against this background the Supreme Court has confronted directly the liability of a nonparty for impeding the administration of justice in MacMillan Bloedel $v$ Simpson. The action arose out of the continuing protests against milling old growth forests in British Columbia. In numerous proceedings the plaintiffs successfully obtained a series of interlocutory injunctions aimed at preventing protesters from blocking logging operations. The orders had named defendants followed by a general description addressed to "John and Jane Doe and Persons Unknown", and, "all persons having notice of the order". The defendant in the proceedings before the Supreme Court fell into the latter category. After the orders had been issued the police arrested over 800 individuals during 1993 for violating the interlocutory orders. The orders specifically authorised police involvement to both supervise the orders and to prevent breaches of the peace. 625 people were convicted of criminal contempt of court and sanctioned by fines up to $\$ 3000$ and jail terms up to 60 days. MacMillan Bloedel never brought civil proceedings against the individual defendants, and by the time the appeals to the interlocutory injunctions were heard, they had long since lapsed.

There were essentially three grounds of appeal. The first ground related to the jurisdiction of the court to grant an injunction against the public in a civil matter preventing conduct which properly fell within the criminal law, and, that was amenable to criminal prosecution by the Attorney-General. At the time of the action the Attorney-General had taken the decision not to lodge criminal charges against the protesters, preferring to leave it to the individual affected property owners through the civil courts. Owing to the Attorney-General'sdecision not to act, MacMillan Bloedel had in fact advanced their injunction applications. The Supreme Court characterised the dispute as one between public rights to protest and dissent, and the maintenance of private rights of landholders to use their land. However, the simple decision of the Attorney-General not to take criminal proceedings did not leave the plaintiff without

61 See, for example, Catkey Construction Ltd v Moran (1969) 8 DLR (3d) 413 (Ont HC).

62 Ambivalence by Canadian Courts on this last point has led Courts in other jurisdictions to conclude that the Canadian jurisprudence is confused. See the comments of Browne-Wilkinson VC, and Balcombe LJ in the lower Courts decision in Attorney-General v Newspaper Publishing Plc [1988] 1 Ch 333, 345 and 386(CA), and Maritime Union v Patrick Stevedores Operations [1998] 4 VR 143, 163 (CA) Winneke P for the Court. 
remedy. Where a private litigant's own property rights were affected by criminal conduct the litigant had standing to invoke the court's jurisdiction without the need to seek prior approval of the Attorney-General. This was a simple affirmation by the SupremeCourt of the principles applicable where a private party wishes to bring an action for a public nuisance, and who is individually and specifically affected over other members of the public.

The second ground related to the ability of a court to grant an order against non-parties. The appellants argued that a court could only make an order against a party to the proceedings, and lacked jurisdiction to do otherwise. In the British Columbia Court of Appeal, Wood JA, in dissent, found this argument compelling. ${ }^{63}$ McLachlin J, for the Court, considered this argument from the grounds of existing precedents and from the policy implications that adherence to it would have for the rule of law in Canada.

McLachlin J recognised the difference between being bound by the injunction as a named party, and being bound to obey an injunction because one becomes aware of its terms. McLachlin J did not seek to change this distinction. McLachlin J then rightly asserted that the English courts have held a non-party liable for contempt for obstruction of justice where they have acted independently, and not just for aiding and abetting the named defendant. After analysing the Canadian and English precedents McLachlin J concluded as follows: ${ }^{64}$

It may be confidentlyasserted, therefore, that both English and Canadian authorities support the view that non-parties are bound by injunctions:if non-parties violate injunctions, they are subject to conviction and punishment for contempt of court. The courts have jurisdiction to grant interim injunctions that all people, on pain of contempt, must obey. The only issue - and one which has preoccupied courts both in England and, to a lesser extent, here - is whether the wording of the injunction should warn non-parties that they, too, may be affected by including language enjoining the public, or classes of the public, from committing the prohibited acts. On this point I share the view of .... Estey J in International LongshoremenAssociation: if members of the public may be bound to respect court orders in private suits on pain of being held in contempt, it seems appropriate that the order appraise them of that fact.

On the issue of what relevant policy implications informed the court's decision, McLachlin J asked rhetorically, "what are the dangers of empowering the courts to make orders to protect private interests which all must obey on pain of contempt?" To this, McLachlin J answered, that while maintenance of the rule of law necessitated such jurisdiction and orders, they could only be made where the public has been apprised of the order and given an opportunity to comply. In addition, circumspection must be exercised so that the orders are not drafted in unduly broad terms. Whereas Wood JA, in the Court of Appeal, had concluded that the court

63 MacMillan Bloedal Ltd $v$ Simpson (1994) 118 DLR $\left(4^{\text {th }}\right) 1$ (BCCA).

64 MacMillan Bloedel Ltd v Simpson [1996] 2 SCR 1048, 1064 McLachlin J. 
should not exercise jurisdiction but insist that the Attorney-General act instead, McLachlin J opined that the Court's equitable jurisdiction to grant injunctions was designed to fill the very gap that the Attorney-General's actions in this case had made necessary.

The third ground of appeal raised the issue of whether an action could be launched against unnamed persons using the appellation, John and Jane Doe and Persons Unknown. On this point McLachlin J held that the Court did not have to answer the issue based on its findings that even a non-party was duty bound to comply with a court order. However, she did observe that the argument really raised a matter of pleadings and that no authority had been given which suggested the appellation as invalidating the proceedings or order.

The approach in MacMillan Bloedel does not specifically discuss the constituent elements of the alleged contemptbut suggests that mere knowledge of the injunction and the carrying out of the enjoined act are sufficient. Indeed, although in the lower Courts the non-parties had all been convicted of criminal contempt, it would appear from McLachlin J's judgment that the actions of a non-party in failing to comply with an injunction once they have notice of it, does not necessarily result in a charge of criminal contempt exclusively. In some cases subsequent to MacMillan Bloedel the Courts have been willing to hold a non-party guilty of civil contempt alone. ${ }^{65}$ If criminal contempt is the appropriate charge for non-parties who fail to obey a court injunction then, presumably, the requisite mens rea and actus reus requirements enunciated in United Nurses of Alberta $v$ Alberta $(A G)^{66}$ would be applicable. In that case the majority established that for criminal contempt: ${ }^{67}$

...the Crown must prove that the accused defied or disobeyed a court order in a public way (the actus reus), with intent, knowledge or recklessness as to the fact that the public disobedience will tend to depreciate the authority of the court (the mens rea). The crown must prove these elements beyond a reasonable doubt. As in other criminal offences, however, the necessary mens rea may be inferred from the circumstances. An open and public defiance of a court order will tend to depreciate the authority of the court. Therefore when it is clear the accused must have known his or her act of defiance will be public, it may be inferred that he or she was at least reckless as to whether the authority if the court would be brought into contempt.

See Merck \& Co $v$ Nu-Pharm Inc (2000) 9 CPR (4th) 379 (FCTD) court refusing to strike out pleadings that raised the issue of whether a non-party could be held liable for civil contempt. International Forest Products Ltdv Kern (2001) 94 BCLR (3d) 67 (BCCA) non-parties pled guilty to civil contempt. Appeal on appropriateness of sentences imposed.

$66 \quad$ United Nurses of Alberta $v$ Alberta (AG) [1992] 1 SCR 901.

67 MacMillan Bloedal, above, 933, McLachlin J 
A minority opinion delivered by Cory J, differed in that the actus reus required the Crown to prove that the contemnor's conduct "must cause a serious public injury". 68 In that case the Alberta nurses, who were embroiled in a labour dispute, openly defied a Labour Board order that had been filed in court requiring them to return to work. Cory J found that the actions of the nurses did not constitute a serious public injury in that their actions, while amounting to civil contempt, raised no threat of public violence nor did they flaunt their disobedience publicly. Cory J's demand for actual proof of a "serious public injury" is closer to the United Kingdom requirement, in the context of a criminal contempt allegation for impeding the administration of justice, that the contemnor'sactions must frustrate the main purpose for which the court granted the injunction in the initial proceedings. Both require proof of actual resultant harm (ie either serious public harm or frustrated main purpose), whereas the majority's opinion requires only open public defiance regardless of whether the contemnor's actions have had, or are likely to have, any effect on the administration of justice.

The root cause of the plaintiff's difficulties in MacMillan Bloedel was the decision of the Attorney General for British Columbia not to lay criminal charges against environmental protesters. This raises the issue of when is it appropriate to make resort to equitable injunctive relief when other potential alternatives exist. McLachlin J commented upon the lack of response by the Attorney General to resort to criminal prosecutions, but said that this fact alone did not deprive the private individual of resort to seek relief from a civil court. In a subsequent article written by Amir Attaran ${ }^{69}$ on MacMillan Bloedel the suggestion was made that a better response would be for the plaintiff to seek mandamus against both the Attorney General and the police to do their duty and criminally prosecute the protesters. ${ }^{70}$ This suggestion has itself generated an unusual amount of judicial commentary. The idea was rejected by the British Columbia Court of Appeal in International Forest Products Ltd v Kern ${ }^{71}$ largely on the basis that the Court accepted the assertions by the AttorneyGeneral that the civil injunction and contempt process was more effective in that it was expeditious and avoided the technicalities of rarely used Criminal Code provisions. However, at least two lower Court

68 MacMillan Bloedal, above, 913, Cory J.

69 Amin Attaran "Mandamus in the Enforcement of the Criminal Law: Ending the Anti-Protest Injunction Habit - Issues arising from MacMillan Bloedel" (1999) 33 UBCLRev 181.

70 See also the suggestion of Southin JA in Everywoman's Health Centre Society v Bridges (1990), 54 BCLR (2d) 273, 285 (CA).

71 See Merck \& Co v Nu-Pharm Inc (2000)9 CPR (4th) 379 (FCTD) where the court refused to strike out pleadings that raised the issue of whether a non-party could beheld liable for civil contempt. In International Forest Products Ltd v Kern (2001) 94 BCLR (3d) 67 (BCCA) non-parties pled guilty to civil contempt. Appeal on appropriateness of sentences imposed. 
decisions have expressed merit in the proposal. ${ }^{2}$ Indeed, the judgment of McEwan J in Slocan Forest Products Ltd $v$ John Doe ${ }^{73}$ raises a disturbing picture of how the use of the civil injunction and commensurate contempt proceedings has become the preferred method of handling all protesters and civil disobedience in the West Coast lumber disputes. The invidious position of the Court is that it is forced to sacrifice its own public esteem and authority to preserve the Attorney General's in what is an extremely heated and politically sensitive climate. ${ }^{74}$ The repeated frequency of this form of action threatens to lower the public's perception of the courts as independent dispensers of law and turn them into a pseudolegislative arm of the forestry industry. It was largely a similar argument that lead Cory J to exercise extreme caution in deciding whether to hold the Alberta nurses for criminal contempt in their labour dispute - namely a fear that public perceptionof courts in labour disputes would be to see the court as an arm of government to impose crushing penalties on trade unions. The lack of involvement of the Attorney General also has other interesting ramifications. As pointed out by Julia Lawn in her article, ${ }^{75}$ because the dispute is kept at the level of private civil litigation, the ability to raise Charter arguments is lost. Yet, these same arguments may have a real bearing on the granting and breadth of the injunction where it impacts upon rights of protest and speech.

MacMillan Bloedel dealt with an interlocutory injunction. If the injunction were a final order McLachlin J suggested a more cautious approach is warranted. Unfortunately, although the theoretical demarcation between final and interlocutory relief is clear, procedural practicalities are a little less so. Often, the plaintiff has no intention to proceed to judgmentafter gaining an effective interlocutory order. Indeed, the plaintiff in MacMillan Bloedel never proceeded to final judgment against the named defendants. The lack of effective time limits on the validity of interlocutory orders can also result in contempt proceedingsbeing brought years after the injunction was granted.

Apart from cost and inconvenience, it is still possible for any named defendant to defend in interlocutory proceedings and to have his or her day in court. In the case of contempt proceedings against a named defendant it is always possible for the defendant to argue over the Forest Products Ltd v John Doe [2000] BCJ No 1592 (July 21, 2000)(BCSC).

73 Slocan Forest Products Ltd $v$ John Doe, above.

74 The irony that the Attorney General who initially washed his hands of the fray in deciding not to prosecute criminally protesters, then returned to lead the charge where a charge of criminal contempt was laid, has not been lost on some. See J Lawn "The John Doe Injunction in Mass Protest Cases" (1998) 56 U of T Fac L Rev 101, 108. the arguments that can be raised when it is the Attorney General who seeks the injunction to prevent civil unrest. 
propriety of the original order, although they may be required to purge their contempt before being allowed to continue their defence. ${ }^{76}$ However, in the case of a non-party the only issue for the Court is whether they have committed the contempt alleged. Because there is no action between the parties there is nothing for the non-party to contest. In fact the validity of the injunction is quite irrelevant because even an invalid injunction must be obeyed until it is set aside. ${ }^{77}$ In addition, because the mens rea element of the contempt only focusses upon whether the non-party has the requisite intent to act in defiance of the court's order, which can itself be inferred from acting publicly, ${ }^{78}$ a non-party never has an opportunity to explain why he or she acted in defiance of the court order, or why the order should not have been granted in the first place. As Julia Lawn identifies, the protesters in MacMillan Bloedel found the Court's disinterest in their substantive merits for acting the way they had, quite bizarre. In contrast, Cory J in his dissenting opinion in United Nurses of Alberta $v$ Alberta (AG) thought the fact that the leader of the Alberta Nurses Association acted with reticence when being interviewed by the media, refrained to agree with a reporter's suggestion that the "law was an ass", and simply presented the nurses' grievances with their employer so as to minimize any disrespect shown to the court, were all relevant to determine whether the charge of criminal contempt, as against civil contempt, had been proved. Under the majority's approach these considerations were irrelevant. This is not to suggest that Cory J would have decided differently in MacMillan Bloedel, indeed he was part of the Court that heard that case and did not render his own judgment, however, I do suggest that the criteria established by Cory J to determine criminal contempt would at least permit non-parties to raise issues on why they acted the way they had and why their actions did not amount to a public injury.

A fundamental principle of our justice system is the right to be heard before being made subject to a court order. A central problem with the way that the law has developedin Canada is that, not only have non-parties been deprived of a right to be heard before an order is made, but that they have been deprived of any right to be heard at all. This position is exacerbated when the plaintiff's action is brought either ex parte, or against the anthropomorphic John and Jane Doe, and has only had to meet a fairly low threshold test, without challenge froma known named defendant, before being granted an interlocutory injunction. While a similar position

76 Ontario (Attorney-General) v Paul Magder Furs Ltd (1991) 6 OR (3d) 188 (CA).

77 Canada (Human Rights Commission) v Canadian Liberty Net [1998] 1 SCR 626.

78 In United Nurses of Alberta $v$ Alberta (AG) [1992] 1 SCR 901, 913, Cory J points out the difficulty in the majority's judgment which made acting in public the central feature of the distinction between civil and criminal contempt. Such an approach replaces the functional distinction between civil and criminal contempt (ie the former focussing uponensuring that the plaintiff's interest in gaining compliance are met, the latter focussing upon the court's interest in having its orders obeyed so that the administration of justice is not lead into disrepute) with one purely centred on the publicity attached to the contemnor's act. 
prevails in the United Kingdom, it is mitigated by the generally more circumspect reverencegiven to the notion that equity can only act in personam, and, further, the stringent requirement that the person who interferes or impedes the administration of justice must actually be proven to have achieved, and intended, that result before being found guilty of criminal contempt.

If Canadian Courts are adamant in the direction they are currently heading, they may think it appropriate to pick up on a suggestion made by Balcombe LJ in the Court of Appeal decision in $A-G v$ Newspaper Publishing $P l c^{79}$ that the plaintiff should be required to seek directly an injunction that is intended to have effect beyond the named defendants and to argue its merits at that time as a principled exception to the rule that equity only acts in personam. An alternative approach to the liability of non-parties is to regularise their status by incorporating theminto the existing civil litigation procedure. One way of doing that is to bring an action against a representative defendant, the other is the use of the John and Jane Doe nomenclature in the cause of action. An alternative, and one suggested by Anderson $J$ in the New Zealand Court, is the appointment of an amicus curiae to advise the Court on the rights of the non-represented parties. ${ }^{80}$

\section{THE AVAILABILITY OF SPECIFIC PERFORMANCE - SEMELHAGO V PARAMADEVAN ${ }^{81}$}

Up until 5 years ago real estate lawyers in Canada could safely have assumed that specific performance was the presumptive remedy for a contract concerning the sale of real property. The idea that land was considered unique per se, and that damages were therefore presumptively inadequate, was taken as unassailable. Both the Supreme Court of Canada in Kloepfer Wholesale Hardware \& Automotive Co Ltd $v$ RG Roy ${ }^{82}$ and the Ontario Court of Appeal in Bashir $v$ Koper, ${ }^{83}$ had asserted as much. There were always some clouds on the horizon. The Supreme Court of Canada had indicated in Asamera Oil Corp Ltd v Sea Oil $\mathcal{E}$ General Corp, ${ }^{84}$ that a plaintiff would have to demonstrate some substantial and legitimate interest in pursuing a specific performance decree, but then, that had been a contract concerning

Attorney-General v Newspapers Publishing Plc [1988] 1 Ch 333, 388-390 (CA) Lord Donaldson MR. Lord Donaldson MR's approach was itself endorsed in Attorney-General v Newspaper Publishing Plc [1992] 1 AC 191 (HL) Lord Bingham CJ. See also S Auerback "Third Parties and Contempt: the Spycatcher case" (1988) 17 Industrial LJ 46 at 49.

80 Tony Blain Pty Ltd v Splain [1993] 3 NZLR 185 (HC).

81 Some of the material in this section is taken from the author's book, Jeffrey Berryman The Law of Equitable Remedies (Irwin Law, Toronto, 2000).

82 Kloepfer Wholesale Hardware \& Automotive Co. Ltd v RG Roy [1952] 2 SCR 465

83 Bashir $v$ Koper (1983) 40 OR (2d) 758 (CA).

$84 \quad$ Asamera Oil Corp Ltd v Sea Oil E General Corp [1979] 1 SCR 633. 
personalty. Some other lower court decisions also forewarned of trouble, ${ }^{85}$ but these had not disturbed the sedate waters of real estate practice.

In Semelhago $v$ Paramadevan ${ }^{86}$ the Supreme Court of Canada seized the opportunity to review the traditional approach to the availability of specific performance. The appellant, vendor, refused to close a real estate transaction for the sale of his residential home. The respondent, purchaser, agreed to buy the appellant's home for $\$ 205,000$. The deal was to be financed by a cash payment of $\$ 75,000$ and $\$ 130,000$ raised on a mortgage of the purchaser's existing home. The purchaser intended to sell his existing home within a six-month period of completion of his new home and had taken an open mortgage over his existing home for this period. At the time of completion, October 1986, the purchaser's existing home was worth $\$ 190,000$. At the time of trial, November 1990 , it was worth $\$ 300,000$. The vendor's home was worth $\$ 325,000$ at the date of trial. At the trial the purchaser elected to take damages rather than specific performance. The trial judge awardedthe purchaser $\$ 120,000$, being the difference in contract price and market value of the vendor's home at the date of trial. Such an assessment was in keeping with the Court of Appeal's decision in 306793 Ontario Ltd in Trust $v$ Rimes. ${ }^{87}$ The vendor appealed this assessment arguing that such an award amounted to a windfall, because the purchaser not only received the increase in value of the property he was going to buy, but also kept the increase in value of the house which they already owned, but which was to be sold to finance the purchase of the new home. An alternative assessment proposed by the vendor, but rejected by the trial judge, simply computed the difference between the increase experienced by the vendor on his house and the increase experienced by the purchaser retaining his existing house. Another alternative, suggested by the purchaser, computed the increase in value on the vendor's house less the costs incurred by the purchaser to achieve that increase, namely, the carrying costs of the $\$ 130,000$ mortgage between closing and trial dates, less the notional interest the purchaser would have made on investing the cash payment of $\$ 75,000$ for the same period. This quantified damages as $\$ 80,810$. The Court of Appeal accepted this last alternative.

The vendor appealed to the Supreme Court of Canada. The issue before the Supreme Court was simply the appropriate damage assessment principle. The Supreme Court reluctantly affirmed the approach taken by the Court of Appeal. ${ }^{88}$ However, Sopinka J, speaking for the

85 See Jeff Berryman "Specific Performance, Uniqueness and Investment Contracts: A Canadian Perspective" [1984] The Conveyancer 130.

86 Semelhago v Paramadevan [1996] 2 SCR 415.

87306793 Ontario Ltd in Trust $v$ Rimes (1979) 25 OR (2d) 79 (CA), leave to appeal refused [1979] 2 SCR xi.

88 One of the difficultieswith the Court's damage assessment is that it makes no account of the lost opportunity experienced by the purchaser in not gaining occupancy of the house while the defendant vendor disputed liability. These costs could be measured by the rental value of the 
majority also took the opportunity to make comment on the appropriateness of seeking specific performance. LaForest J declined to address this issue without the advantage of argument. Sopinka J first suggested that any generosityin damage assessment in these types of cases is only justified if the property is unique: ${ }^{89}$

...While at one time the common law regarded every piece of real estate to be unique, with the progress of modern real estate development this is no longer the case. Both residential, business and industrial properties are mass produced much in the same way as other consumer products. If a deal falls through for one property, another isfrequently, though not always, readily available.

It is no longer appropriate, therefore, to maintain a distinction in the approach to specific performance as between realty and personalty. It cannot be assumed that damages for breach of contract for the purchase and sale of real estate will be an inadequate remedy in all cases.

Courts have tended, however, to simply treat all real estate as being unique and to decree specific performance unless there was some other reason for refusing equitable relief...

Specific performanceshould, therefore,not be granted as a matter of course absent evidence that the property is unique to the extent that its substitute would not be readily available.

Sopinka J went on to endorse the approach taken by Estey J in Asamera to the effect that there must be "somefair, real and substantialjustification" for the claim to specific performance. Had Sopinka J been trying this case de novo the purchaser would not have met this standard. The parties had been both content to present the case on the basis that the purchaser had been entitled to specific performance.

The difficulty with specific performance as a presumptive remedy in real estate contracts is that upon breach it obviates the need for the plaintiff to mitigate. The plaintiff must simply continue to be ready and willing to perform his or her contract. There are sound policy reasons supporting a general duty to mitigate loss, a point accepted in almost all other actions for breach of contract. Briefly, those benefits are; one, it aids economic efficiency if the defendant is at liberty to enter into contracts with parties who place a higher value on the commodity the defendant is selling, than being forced to sell to the plaintiff provided the plaintiff can have his or her expectation compensated in damages. Two, it is appropriate to expect the plaintiff to mitigate because the plaintiff is in the best position to know what substitute performance he or she will accept. Three, it would entail delays in market turnover if the defendant always had to be in a position to render performance pending the plaintiff's successful court action for breach. Four, it prevents the plaintiff from exploiting his or her position in seeking to gain some

vendor's home, or the expenditures saved by the vendor in not having to find alternative accommodation. 
of the profits the defendant would make from breach in return for giving up a specific performance decree. This exploitative gain has no bearing to the plaintiff's actual losses.

Specific performance is justified where the plaintiff will suffer a loss not readily compensated in damages. This will arise where the plaintiff has a subjective value based upon his or her own idiosyncratic values attached to a particular property he or she is buying. This interest is often referred to as "consumer surplus". ${ }^{90}$ While the concept of uniqueness is built around the protection of this type of interest, there has traditionally been a natural suspicion and scepticism of a plaintiff who makes what is, largely and objectively, an unprovable assertion. Consumer surplus is infrequently compensated in other contracts. Certainly, where a plaintiff is purchasing other than for his or her own use and enjoyment it is difficult to argue that consumer surplus can be present. If the plaintiff is purchasing real estate for investment purposes it is perplexing to see why he or she should be treated differently from any other investor investing in other types of commodities.

In Canada, to prove that the plaintiff has some fair, real and substantial justification for specific performance now requires the plaintiff to demonstrate how damages are an inadequate remedy. This approach will presumably reconcile the availability of specific performance with the position taken when seeking other equitable remedies. It also requires Courts to articulate inadequacy criteria in a much more systematic way than has been done in the past. A lower Court decision by Adams J in Domowicz v Orsa Investments Ltd $^{91}$ has provided a good starting point. In that case, the plaintiff, incidentally a lawyer, together with other members of his family, commenced investing in apartment buildings. They entered into the purchase of an apartment complex from the defendants to close in 1986. The sale did not in fact close and the plaintiffs were successful in gaining summary judgment for specific performance in 1987. The Court of Appeal set that judgment aside. The matter then came back on trial in 1993. The parties were unable to resolve their dispute and brought the action forward to determine whether specific performance was available, and what damages would follow if it was not. On the availability of specific relief, Adams J cited extensively from academic commentaries about the nature of contracting and the paramountcy of damages as a remedy. The common law always sought to limit a promisee's damages by requiring certainty, foreseeability, and denying recovery for avoidable losses. Specific performance frustrates all three limitations, but particularly that relating to avoidable losses or the obligation to mitigate. After reviewing the case law that supported a presumption of specific relief, Adams J saw reconciliation with contract doctrine on the bases of a rebuttable presumption. What was

90 See D Harris, A Ogus, and J Phillips "Contract Remedies and the Consumer Surplus" (1979) 95 LQR 581. 
required was a real exploration of the inadequacy of monetary relief after scrutiny of the transaction

In reviewing the facts of this case, Adams J pointed to at least three categories of attributes that may support the plaintiff's right to specific performance based on inadequacy of damages. First, he noted the particularphysical characteristics of the property. In evidence the plaintiffs tried to suggest this property had unique features that made it particularly desirable as an apartment block. Some of these characteristics included its street level parking, its red brick rather than white glazed brick exterior, its state of good repair, its lack of close proximity to other similar high rise buildings, its east/ west location, and its suite mix. Adams J singularly dealt with each of these matters and concluded that other properties on the market in the vicinity had comparable characteristics. Some of these characteristics, Adams J dismissed as post facto reasons raised to justify pursuit of specific performance. Second, were the particular transactional characteristics of this property. Much turned on the ability of new owners to seek rent review as a way to increase the return on the property; although, subsequent legislative changes dramatically altered this potential. This argument proved to be something of a two-edged sword for the plaintiffs because Adams J saw in the financing and rent review increases, the incentive to quickly turn the building over which undermined the plaintiffs' assertions that they intended to hold onto the property for a long period. Third, were the personal or subjective attributes of the plaintiffs in wishing to purchase this particular building. The plaintiffs asserted that the building was being acquired for one of the plaintiff's retirement. Again, this proved unconvincing in that the plaintiff was in his late thirties and that another property had been purchased by the plaintiffs the same day and sold one year later. In the subsequent action on assessment of damages, Adams J confined the plaintiffs to damages measured as the difference in contract and market price assessed at a reasonable period after the breach, being three months, at which point the plaintiffs could reasonably have been expected to have found a similar investment property, mitigating their losses. ${ }^{92}$

Adams J alludes to at least three types of inadequacy or characteristics of uniqueness; the physical attributes of the property, the commercial or transactional attributes, and, personal factors of the purchaser. Traditionally, our civil law has confined itself to the first type of inadequacy. As the inadequacy criteria becomes the controlling feature of specific performance, Canadian lawyers will no doubt have to work toward a clearer understanding of inadequacy of damages. The recognition of commercial uniqueness - the transaction attributes - should be welcome, although they will probably carry additional evidential burdens. Inadequacy of monetary relief may take other forms. Difficulties in damages quantification may be one such feature. The financial incapacity of the defendant to pay may be another. These characteristics 
would not normally be considered under the rubric of uniqueness but have been considered when determining the availability of injunctions under the guise of inadequacy of damages. ${ }^{93}$

In the decisions since Semelhago Canadian Courts have begun to formulate approaches on how to assess inadequacy, although not in a systematic way. Some have indicated that the Supreme Court's judgmentsignificantly qualified the concept of uniqueness and stressed that the "property only has to be unique to the extent that a substitute is not readily available".94 Although Adams J in Domowicz still spoke of a rebuttable presumption in favour of specific performance, the cases subsequent to Semelhago recognise that there is no longer any such presumption operating in Canada. ${ }^{95}$ The burden of proof lies on the person requesting the remedy.

Most decisions have recognised that the test is a question of fact to be decided on the particular circumstances involving subjective and objective elements. ${ }^{96}$ Plans that the plaintiff has for the property may be relevant to determinewhether a substitute can be readily found, but the likelihood of success of those plans is irrelevant. Thus, a developer who wished to purchase land adjoining property he already owned so that it could be redeveloped was still entitled to specific performance even where the vendor demonstrated that the chance of getting municipal planning approval and other affectedowners' consent was problematic. As the court explained, without the property to parcel with the purchaser'sexisting holding, his plans could never be put to the municipality. ${ }^{97}$ A plea for specific performance where there is a drop in market price has been held to be a strong indicator that the property has personal subjective attributes for the purchaser as it appears to be against self-interest. ${ }^{98}$ The test for determining uniqueness has also been held to apply when the plaintiff elects to pursue specific performance

93 These ideas are already ashore in New Zealand. See the obiter dicta of Hammond J Butler v Countrywide Finance Ltd [1993] 3 NZLR 623, 636 (HC).

94 Greenforco Holding Corp. v Yonge-Merton Developments Ltd [1999] OJ No 3232 (June 25, 1999)(SC) Appeal dismissed [2000] OJ No 3748, further leave to appeal to SC denied [2000] SCCA No 613, and Konjevic v Horvat Properties Ltd (1998) 40 OR (3d) 633 (CA).

9511 Suntract Holdings Ltd $v$ Chassis Service \& Hydraulics Ltd (1997) 36 OR (3d) 328 (Gen Div). The decision of the Ontario Court of Appeal in Landmark of Thornhill Ltd $v$ Jacobson (1995) 25 OR (3d) 628 , in which a vendor and developer of condominiums was awarded specific performance, presented a contrary view. In that case the Court indicated that the burden was upon the purchaser to prove that the condominium was not unique and rebut the presumption that favoured the plaintiff vendor. However, this decision was decided prior to Semelhago.

96 Taberner $v$ Ernest \& Twins Developments Inc [2001] BCJ No 429 (March 8, 2001)(BCSC), and Greenforco Holding Corp, above.

9711 Suntract Holdings Ltd, above.

$98 \quad$ Taberner $v$ Ernest, above. 
in the face of the defendant's repudiation and not when the contract was entered. ${ }^{99}$ It has become harder for a commercial developer to gain specific performance ${ }^{100}$ and for investors seeking to flip land or purchase for the land's investment potential alone. ${ }^{101}$ Similarly, a vendor's action for specific performance is difficult to maintain, ${ }^{102}$ although not impossible. ${ }^{103}$

\section{V "KEEP OPEN" CLAUSES AND REMEDY STIPULATION ${ }^{104}$}

Two phenomena have changed retailing in our acquisitive society; the shopping mall and the big box store. Central to both is an anchor tenant with consumer drawing power so that other smaller retail operations are able to prosper in the light of the anchor tenant. However, the smaller retailer pays a premium to be part of this symbiotic relationship by way of higher lease payments; the large retailer receives a commensurate reduction through sheer strength of bargaining position. This arrangement works as long as the large retailer continues to operate and competition is kept at bay. Fickle consumers are attracted to the "new"; therefore, retailers must constantly revamp their image and reposition themselves in the marketplace. For the large retailer, modernisation may be achieved by moving to new premises at a different location. Keeping the competition at bay may be achieved by ensuring that a competitor does not occupy the space vacated. Continuing to pay the lease payments and running a low level operation in an "old" location can be a prudent business decision for the large retailer, but with devastating effects on other smaller retailers. For the landlord in such arrangements, stability can be achieved if the anchor tenant can be forced to perform. Clauses requiring the anchor tenant to "keep open" or promise to remain "continuously open" are standard practice, however, their enforcement is now being vigorously tested.

The decision of the House of Lords in Co-operative Insurance Society Ltd v Argyll Stores (Holdings) $L t d^{105}$ is the most recent discussion of this issue from a senior appellate level Court in the common law world. In that case two experienced commercial entities had entered into a

99

100 Richcraft Construction Ltd v National Capital Commission [1999] FCJ No 1959 (December 16, 1999)(FCTD); Rostrum Development Corpv Wafler [1996] BCJ No 2672 (December 27, 1996)(BCSC); and Monson $v$ West Barrhaven Development Inc [2000] OJ No 5209 (December 22, 2000)(Ont Sup $\mathrm{Ct}$ ).

1011174538 Ontario Ltd v Barzel Windsor (1984) Inc [2001] OJ No 5091 (December 27, 2000)(Ont Sup $\mathrm{Ct})$.

Taylor v Sturgeon (1996) 156 NSR (2d) 147 (HC).

103

Hoover v Mark Minor Homes Inc (1998), 75 OTC 165 (Ont Gen Div).

Some of this material is reproduced from the author's book, Jeffrey Berryman The Law of Equitable Remedies (Irwin Law, Toronto, 2000).

\footnotetext{
Co-operative Insurance Society Ltd v Argyll Stores (Holdings) Ltd [1998] 1 AC 1 (HL).
} 
long term commercial lease in which the tenant, Argyll, was obliged to "keep open" its supermarket during usual hours of business for the locality. Argyll, who ran a major chain of supermarkets throughout the United Kingdom, was in fact the anchor tenant in the plaintiff's shopping complex. After undertaking a review of its business operations Argyll decided to close down its store in the plaintiff's mall. This decision was made as part of a restructuring of the defendant's operations in which 27 loss-making or marginally profitable stores were closed. The defendant's store in the plaintiff's mall had been running an annual loss of $£ 70,000$. In the trial court, the plaintiff had sought specific performance requiring the defendant to continue to keep open its store for approximately nineteen years, the remainder of the lease period. The trial judge had rejected the plaintiff's request, confining it to damages, and citing a long established rule against granting specific relief requiring a person to continue running a business. In the Court of Appeal, the majority granted the specific performance decree, paying particular attention to the "gross commercial cynicism"and "wanton and unreasonable conduct" of the defendant.

The House of Lords reversed the Court of Appeal's decision and restored the trial judge's original order. In doing so Lord Hoffmann, the other Lords concurring, sought to clarify the law regarding specific performance and difficulties with supervision. Prior to this decision there had been emerging a trend to liberalise the availability of specific performance and to overcome apparent difficulties with court supervision of the decree. ${ }^{106}$ On one level Lord Hoffmann confirmed that the prospect of constant supervision requiring the use of court personnel is not the reason for restraint in granting the decree. However, the interplay of the use of coercive powers - committal for contempt, and the prospect of repeated breaches of the order requiring multiplicity of suits - does justify restraint. In Lord Hoffmann's opinion, the threat of committal for contempt adversely impacts on the defendant's commercial reputation creating an inimical climate in which to operate a business. Further, the seriousness of the finding will result in a heightened sense being accorded the litigation leading to expensive and possible repeated actions before the court over a prolonged period of time. Lord Hoffmann used the latter reason as a justification for distinguishing between orders that required a defendant to carry on an activity, as in running a business, and orders that required the defendant to achieve a result, as in completing a building. The prospect of repeated applications is viewed as being more likely in the former than in the latter. In addition, the framing of an order is likely to be more difficult to ensure compliance in regard to an activity as against a result. It is not enough that the contractual obligation is described in sufficiently precise terms so as to escape scrutiny under the doctrines of contractual uncertainty. The requirement that the order be expressed in precise language to ensure the defendant knows what is required necessitates a higher level of exactitude. Lord Hoffmann was also concerned about the effect that granting

106 See, for instance, the decision of Mervyn Davies J in Posner v Scott-Lewis [1987] 1 Ch 25 and Megarry J in Tito v Waddell (No2) [1977] Ch 106. 
specific performance would have by arming the plaintiff with a means to extract a higher price in return for releasing the defendant from the "keep open" obligation. The lease had allowed for an assignment, an act that had in fact taken place before the appeal to the House of Lords. On this point Lord Hoffmann reiterated that a specific performance order was not the place to undermine the contractual rules relating to damage compensation being a measure of the plaintiff's actual losses and turning that order into a mechanism to extract profits made by the defendant through breach.

The net effect of the decision in Argyll is to dismiss judicial concerns over the deployment of actual resources to supervise a specific performance decree, but to elevate concerns over the prospect of repeated applications by the plaintiff to ensure compliance. Based on these concerns the House of Lords created a demarcation between specific performance of an "activity" as against a "result" that makes it problematic to ever get a specific performance requiring a defendant to continue operating a business.

Part of the difficulty in Argyll is the belief of the House of Lords that once a specific performance decree has been awarded it is considered final. This opinion results in the inability of litigants ever returning to court to seek a change in the court's order based on changed circumstances and where the continued enforcement of the order would constitute oppression. Of concern in Argyll was that if a defendant was required to continue operating its store at a loss it may at some subsequent time face insolvency. In the actual case there was no suggestion that the defendant, a national food chain, would face insolvency if forced to keep open the store in question. Tettenborn has criticised this aspect of the judgment. ${ }^{107}$ It also appears to be inconsistent with the House of Lord's own judgment in Johnson $v$ Agnew. ${ }^{108}$ There, the non-performance of a specific performance decree remained a continuing breach of the contract conferring upon the plaintiff the right to bring an action in common law for breach and to seek damages. In Ontario, the Court of Appeal recently affirmed the notion that once specific performance has been decreed the contract comes under the management and control of the court, and presumably, can be changed at any time on the suit of either party. ${ }^{109}$ Thus, it seems quite appropriate for a court to grant specific relief, where the problems with supervision remain hypothetical and speculative, until such time as the parties incur any difficulty. At that stage the court could reassess its decision to persevere with the contract and bring the relationship to an end by requiring the plaintiff to crystallize its loss in damages. Where problems with supervision arise immediately, for instance, the inability to describe what has to be done; the court should refuse the specific performance decree forthwith.

107 A M Tettenborn"Absolving the Underserving:Shopping Centres, Specific Performance and the Law of Contract" [1998] The Conveyancer 23.

108 Johnson v Agnew [1980] AC 367 (HL).

$109 \quad$ Lubben $v$ Veltri \& Sons Corp (1997) 32 OR (3d) 65 (CA). 
Canadian cases have by and large followed Argyll and there is a long pedigree to the effect that specific performance will not be given in these circumstances owing to the difficulty of court supervision. ${ }^{110}$ Nevertheless, there are also rumblings that this position may well change in the future. Most recently the Manitoba Court of Appeal has commented on this issue in Nickel Developments Ltd v Canada Safeway Ltd. ${ }^{111}$ The plaintiff sought a declaration that the defendant was bound to observe a provision in a long term lease which obligated the defendant to continuously operate a grocery store as an anchor tenant in the plaintiff's mall. The plaintiff had purpose built the store to the defendant'sspecificationsand it had beenleased and operated by the defendant for over 15 years. The lease had to run one more five-year renewal period when the defendant ceased operation. However, the defendant renewed the lease so as to prevent any competition occupying the store. The store operated in a small northern mining city and the defendant had decided to concentrate all its operations at one new store. A majority of the Court granted the plaintiff its declaration that the defendant was obligated to continuously operate a grocery store for the remainder of the renewed lease period. ${ }^{112}$ Obviously, a declaration does not necessarily mean the plaintiff would get specific performance. However, the Court does comment on the nature of the relationship of landlord to anchor tenant. In this case the andhor tenant received a purpose-built building together with a non-competition clause excluding other similar type stores as a retail mix in the mall. There were "significant and intended advantages", in return the defendant assumed an obligation to continuously run a supermarket knowing that attracting clientele to the mall was a "central theme" of the lease operation. The presence of a right to assign the lease did not change the nature of this relationship, and, in fact, the decision to simply turn out the lights rather than make genuine efforts to find a sub-lessee threw doubt on the good faith of the defendant.

The British Columbia Court of Appeal has also indicated it may revise its approach to the orthodox position if it can be demonstrated that it is unfair to both landlord and other tenants. 113

110 The cases have been gathered in R Sharpe Injunctions and Specific Performance (2nd ed, Canada Law Book, looseleaf) 19.360 . Contrast the position in Scotland where it has recently been affirmed that specific performance can be made of a keep-open clause and that issues concerning enforcing a defendant to run his or herbusiness at a loss are downplayed unless there is strong evidence that such a result will ensue. Highland and Universal Properties Ltd $v$ Safeway Properties Ltd [2000] Sessions Cases 297, [2000] SLT 414 (Scot Court of Sessions).

111 Nickel Developments Ltd v Canada Safeway Ltd (2001) 199 DLR (4th) 629 (Man CA).

112 Twaddle J in minority, did not find an obligation of continuous use either expressed or implied in the agreement.

113 AL Sott Financial (Newton) Inc v Vancouver City Savings Credit Union [2000] BCJ No 499 (March 9, 2000)(BCCA). 
In Bentall Properties Ltd $v$ Canada Safeway $L_{t} d^{114}$ the British Columbia Supreme Court granted an interlocutory injunction preventing the defendant from closing its supermarket pending the determination of a disagreement over the operating covenant in the lease. The court determined that should the interlocutory injunction be denied the potential loss to the plaintiff would be difficult to quantify; whereas, the defendant's losses could be quantified, satisfying the American Cyanamid v Ethicon $\mathrm{Ltd}^{115}$ test for interlocutory relief. In this case the defendant was one of several anchor tenants in a large mall in a region city of British Columbia. The other anchor tenants communicated to the plaintiff that if the defendant left, they might also close their stores. In addition, other tenants operating smaller retailing outlets had clauses that allowed them to reopen their leases should an anchor tenant leave. The loss of an anchor tenant would also jeopardise renewal of existing tenants as their leases came up for renewal. ${ }^{116}$

What is often lost in these cases is that, absent a presumption favouring specific performance of realty contracts, the grant of specific relief is conditional upon a determination that damages are an inadequate remedy. I would suggest there is a growing sense of unease that damages are an adequate relief in cases involving the default of an anchor tenant. The consequences of default, as explained in Bentall illustrates just how problematic damage quantification may prove. ${ }^{117}$ For the mall operator the lease to an anchor tenant has repercussions for all other tenants whose own lease payments may be linked to a partial percentage of turnover or profit. Similarly, the landlord may be attempting to keep a certain store mix to maximize the likelihood that customers will be attracted to the mall. These intangibles are difficult to quantify with any precision. Clearly, by seeking specific relief, the landlord has made an initial assessment that damages are inadequate. The traditional concern of courts over the problem of supervision and the fear of resources being devoted to ensure compliance has given way to the opinion that heavy-handed coercive remedies, which may generate multiple suits, are inappropriate for contractual breach.

It is clear that the former rationale had to give way in light of the approach that courts are now required to take to modern bankruptcy proceedings where court supervision and multiple suits are a fact of life. Replacing this approach with a rationale based on heavy handedness and the fear of multiple proceedings is not prudent. I have suggested a wait and see approach. Grant the specific performance decree and then see if fear of multiple suits is in fact generated. If it does eventuate, a court may always bring the proceedings to a close by reverting to

114 Bentall Properties Ltd v Canada Safeway Ltd [1988] BCJ No 775 (May 19, 1988)(BCSC).

115 American Cyanamid v Ethicon Ltd [1975] AC 396 (HL).

116 See also Centre City Capital Ltd $v$ Great Atlantic E Pacific Co of Canada (22 August 1988) Ont HC and noted in 566719 Ontario Ltd v New Miracle Food Mart Inc (1994) 41 RPR (2d) 22 (Ont Gen Div).

117 See also A Kaufman "Operating Clauses in Shopping Centre Leases: Lights Out for the Vacating Tenant" (1991) 18 Can Bus LJ 245. 
damages. In the House of Lords the Court dismissed the idea that once granted, an anchor tenant's desire to preserveits business reputation would result in the tenant fully discharging its lease obligations without the need for further court intervention. For their Lords, the loss of business confidence between the parties, and the prospect of having to run a store at a marginal profit or possible loss position was seen as demanding too much from the tenant. Human nature being what it is, this was a recipe for acrimony and non-compliance. Other courts have been more sanguine on this point suggesting that a defendant's commercial reputation, its "pride and integrity not to let standards slip", may be enough to take care of any supervision question. ${ }^{118}$

In one reported Canadian decision the landlord sought to avoid the likelihood that a commercial lease of an anchor tenant will not be specifically performing by inserting into the terms of the lease a remedy stipulation clause. In Tritav Holdings Ltd $v$ National Bank of Canada ${ }^{119}$ the landlord of a commercial shopping plaza sought an interlocutory injunction and specific performance requiring the defendant bank to reopen its bank in the plaza. The lease contained a clause titled "Failure of the Tenants to Carry on Business" that included a "keep open" provision, a liquidated damages clause, and the tenant's recognition and consent to the landlord seeking an injunction and specific performance to restrain and compel the tenant to reopen its premises. Gotlib J remarked that the "parties cannot contract out of the existing law as it is". The injunction was denied. Because we are dealing with equitable remedies that are within a court's discretion, clauses that purport to fetter the exercise of discretion have not been enforced. However, the presence of such a clause in other situations has served an evidentiary function and assisted the court in determining that damages are an inadequate remedy. ${ }^{120}$

\section{THE CHANGING ROLE OF EQUITABLE COMPENSATION - CADBURY SCHWEPPES INC V FBI FOODS LTD}

In the area of fiduciarylaw, legal developments in Canada present an ever-changingmosaic. Our proximity to the United States means we have been influenced in a way not experienced by other Commonwealth common law countries. In particular, the development of the remedial constructive trust and the concept of "fact based" fiduciaries can be traced to similar developments in the United States. These concepts are not foreignto Australasia, but in Canada

118 See Centre City Capital Ltdv Great Atlantic \& Pacific Co of Canada (22 August 1988) unreported, Ont. HC and noted in 566719 Ontario Ltd $v$ New Miracle Food Mart Inc above. See also the Court of Appeal decision in Co-operative Insurance Society Ltd v Argyll Stores (Holdings) Ltd [1996] Ch 286 (CA).

119 Tritav Holdings Ltd $v$ National Bank of Canada (1996) 47 CPC (3d) 91 (Ont Gen Div).

120 See Warner Brothers Pictures Inc v Nelson [1937] 1 KB 209. 
they are now part of mainstream legal argument. ${ }^{121}$ The development of the "fact-based" fiduciary - one dependent upon finding a factual matrix in which one party can unilaterally exercise power or discretion that affects the legal rights of another who is peculiarly vulnerable to the party exercising that power ${ }^{122}$ - has required Canadian Courts to develop new remedial responses where the traditional proprietary and account remedies for breach of fiduciary duty are inappropriate. One such development has been the attention paid to equitable compensation, as distinct from equitable damages, and whether the principles of quantification should mirror the common law, or, whether there are some other juristic reasons which merit adherence to different principles.

There has been a schism in Canada's Supreme Court on the appropriate role of equitable compensation. One side, represented by McLachlin J (now Chief Justice) and ascribed to by Australian $^{123}$ and English Courts, ${ }^{124}$ and dare I add New Zealand, ${ }^{125}$ view equitable compensation as quite distinct in method of assessment and quantification, extrapolating from trust principles although sometimes drawing, by analogy, support from the common law. The other side, representedby La Forest J, draws a much closer analogy to the commonlaw and will only part from the latter where there are demonstrable policy reasons for doing so. At the heart of this debate is the extent to which classical commonlaw compensatory assessment principles should be used to remedy equitable rights that have their origins within equity's exclusive substantive jurisdiction. If equity does not simply mirror common law approaches then it must develop its own concepts on remoteness and causation, mitigation, limitation periods, contributory negligence and certain evidentiary presumptions. ${ }^{126}$ These issues become particularly acute in Canada where the expansion of fact-based fiduciaries in areas hitherto

121 Donovan Waters "The Reception of Equity in theSupreme Court of Canada (1875-2000)" (2001) 80 Can Bar Rev 676.

122 See Wilson J in Frame v Smith [1987] 2 SCR 99, 136 and P Finn (now a Justice of the Australian Federal Court) The Fiduciary Principle in T Youdan (ed) Equity, Fiduciaries and Trusts (Carswell, Toronto, 1989) 1.

123 Commonwealth Bank of Australia v Smith (1991) 102 ALR 453 (FCA).

$124 \quad$ Target Holdings Ltd $v$ Redferns [1995] 3 All ER 785 (HL).

125 Day v Mead [1987] 2 NZLR443(CA) and BNZv NZ Guardian Trust Co Ltd [1999] 1 NZLR 664(CA). There is a slight schizophrenic quality to the position of the English and New Zealand position. While both endorsing McLachlan J's approach and thereby preserving a distinctive approach to equitable compensationwith respect to causation and remoteness, the actual judgments spend more time articulating reasons for convergence of equitable duty and tortious obligation and that the rules of assessment should therefore be identical. This position is the one pursued by La Forest J

126 See the excellent discussion of these issues in C Rickett and T Gardner "Compensation for Loss in Equity: The Evolution of a Remedy" (1994) 24 VUWLR 19. 
not normally known to attract fiducial obligations has resulted in the creation of a form of an equitable tort regime. ${ }^{127}$ A further point of departure is the extent to which equitable compensation should pursue punishment and deterrence as legitimate goals, or whether these goals should be explicitly recognised by awarding exemplary damages as part of the overall award in any case. ${ }^{128}$

The decision of the Supreme Court of Canada in Cadbury Schweppes Inc v FBI Foods Ltd ${ }^{129}$ is a further evolution of the court's approach to equitable compensation. A company called Duffy-Mott had licensed another company called Caesar Canning to produce Clamato juice. As part of this contract, Duffy-Mott had communicated confidential information about its product to Caesar Canning. Caesar Canning had in turn sub-contracted with FBI Foods to produce the Clamato juice. Subsequently, Caesar Canning went bankrupt and FBI Foods purchased all its assets including the right to produce Clamato juice. Duffy-Mott was itself purchased by Cadbury Schweppes Inc.. After purchasing Duffy-Mott, the plaintiffs terminated the licensing agreement with FBI Foods. Under the original licensing contract, upon termination the appellant was forbidden from using the marketing term "Clamato", and from producing any combination of clam and tomato juice for a period of five years. Following termination the appellant wrongfully utilized the confidential information communicated to it and was able to reproduce the plaintiff's juice without using clamjuice. It then marketed this product under the brand name Caesar Cocktail. The trial judge found that the appellant would have been able to successfully launch a competitive product within twelve months of the termination of the licensing agreement. However, the use of the confidential information gave the appellant a springboard. The trial judge gave damages in the amount a consultant would have charged to assist in developing a new product. The trial judge declined a permanent injunction because of the prolonged delay by the plaintiffs and because much of the confidential information was in the public domain or of little consequence. The Court of Appeal granted an injunction and ordered damages assessed on the profit that the plaintiffs would have made in the twelve months following termination of the licensing agreement. This assessment assumed that the respondents would have sold the same amount of Clamato juice as Caesar Cocktail was sold in that period. (1997) 28 Can Bus LJ 107.

128 I have recently discussed these issues in an article, "Equitable Compensation for Breach of factBased Fiduciaries: Tentative Thoughts on Clarifying Remedial Goals" (1999) 37 Alberta L Rev 95, and see also Donovan Waters "The Reception of Equity in the Supreme Court of Canada (1875-2000)" (2001), 80 Can Bar Rev 679. 
The Supreme Court was thus confronted with determining the appropriate remedy for a breach of confidence. The parties argued that different remedial outcomes turned on the precise jurisdictional and doctrinal parameters of the right to confidence. For the Supreme Court, Binnie J clearly saw the protection of confidences as originating in equity. However, the equitable doctrine could coincide with other causes of action lying in contract, tort and property law. In this sense the jurisdiction of the law of confidence could be said to be sui generis. Binnie J then stressed the need to match the equities of the claim with an appropriate remedy: ${ }^{130}$

In short, whether a breach of confidence in a particular case has a contractual, tortious,

proprietary or trust flavour goes to the appropriateness of a particular equitable remedy but does

not limit the court's jurisdiction to grant it.

The choice of appropriate remedy turned on matching the "remedy to underlying policy objective". One option was to confer a proprietary remedy of constructive trust, or equivalent equitable compensation, of the profits made by the defendant as if its sales were treated as assets that had been "pirated" from the plaintiff. This approach would be favoured if a fiduciary relationshipexisted. The Court could find none, as the relationshiplacked any aspect of surrendering self-interest or personal vulnerability; ${ }^{131}$ nor could a fiduciary duty be found outside the classical framework of fiduciary relationships. The confidentialinformation could not be likened to the estate assets of a trust that had been "pirated" by the defendant.

A second approach was based on the notion that confidential information could be likened to intellectual property, again favouring a proprietary remedy or an account of profits. The court noted the controversy surroundingthe idea that confidentialinformation was "property". The information lacked the "bargain aspect" of intellectual property, where the patentee is given a monopoly in return for complete disclosure. Also significant from an intellectual property approach was that at trial the plaintiff had waived any right to claim disgorgement or an accounting of profits.

A third approach was to award damages in substitution for an injunction under the Lord Cairns' Act. Binnie J noted that under this approach it would be difficult to award damages for any loss that occurred prior to the application for the injunction. In addition, the fact that the trial judge had been disinclined to order an injunction would open up to challenge the jurisdiction to grant equitable damages - had the trial judge declined to grant the injunction based on an exercise of his or her discretion, or because he or she believed there was no jurisdiction to grant an injunction at all?

130 Cadbury Schweppes Inc v FBI Foods Ltd, above, 161, Binnie J.

131 See Waters, above, 678. Commercial relationships between business people bargaining at arm's length will seldom attract the fiduciary designation. 
A fourth approach was an analogy to tort damages. The plaintiff had difficulty with this approach because the trial judgehad found that the information was of little value and that the plaintiff had experienced no financial loss. The Court admitted that different principles may apply to the assessment of common law damages when compared to equitable compensation. However, in this case the assessment under either approach would produce the same result. This conclusion turned on the finding that the basis of compensationwas not the intrinsic value of the informationitself; rather, it was the lost opportunity experiencedby the plaintiff in being able to market its product without the defendant's unfair competition for a year following the termination of the licensing agreement. How was this interest to be calculated? The trial judge had given the plaintiff the equivalent of what a consultant would have charged the defendant to assist in developing their competing product. The Court did not favour this assessment because the plaintiff was never in the business of consulting or selling its trade secrets. In the Court of Appeal the plaintiff was given compensation based upon the profit the plaintiff would have made in selling its own product to the same levels achieved by the defendant in the year following termination of the licensing agreement. The Supreme Court accepted this basis, but required the plaintiff to prove its actual decline in sales rather than assume that the plaintiff would have made all the defendant sales in absence of any competition.

A number of observations can be made on this case. First, it would seem that the role of equitable damages under Lord Cairns' Act is being eclipsed by the explicit recognition of a broad right to grant equitable compensation for breach of an equitable right. At a time when most commentators had accepted that issues of jurisdiction to award equitable damages should be perceived as going to the exercise of discretion, the Supreme Court has raised the spectre that jurisdictional argument on whether an injunction could or could not have been awarded are again alive. However, the plaintiff will now be able to turn to equitable compensation. Two, the decision further strengthens McLachlan J's approach to equitable compensation although much time is spent animating policy factors which suggested the Court should favour, on the facts in this case, the spring-board approach to damage quantification. Three, a plaintiff seeking equitable compensation will find a veritable tabula rasa in which few, if any, rules can be identified on which to quantify damages. At one end of the spectrum equitable compensation can substitute for a constructive trust or other proprietary remedy. The remedial goal is to restore to the plaintiff the value of the property interest expropriated and any gain made from its misuse. This may, or may not, accommodate the expenditures made by the defendant to earn any profit. At other times equitable compensation can mirror tortious damages so that the plaintiff is restored to his or her position status quo ante the breach of equitableright. However, traditional limiting principlessuch as causation and remoteness may not necessarilybe applied, and if so, not with the same outcomes. Here the remedial goal is to restore the plaintiff to the position he or she experienced before the violation of the equitable right. The plaintiff is put to the task of proving its actual losses. At times, this goal is accentuated so as to make the 
defendant the absolute insurer of the plaintiff's losses howsoever caused. ${ }^{132}$ An additional remedial goal is then punishment and either specific or general deterrence. Another approach is to value the plaintiff's foregone opportunity in not being able to voluntarily agree to "sell" violation of his or her equitable rights. Alternatively, the court may measure the plaintiff's losses by attempting to find a market value for the equitable right. Here the remedial goal mirrors that of contract law and seeks to compensate for lost expectation or detrimental reliance as conceived by Fuller and Purdue in their celebrated article. ${ }^{133}$

The approach adopted by the Supreme Court of Canada was similar to the tort of conversion. The plaintiff was entitled to recover its lost sales to the extent that it could prove that they flowed directly from the defendant's violation of the plaintiff's confidential information. The defendant was entitled to compete with the plaintiff; however, it was not entitled to utilise the plaintiff's knowledge to betterits position. Nor was the defendant to be made the absolute insurer of the plaintiff's lost market share.

A fourth point of note is the contrast between an all-encompassing approach to equitable compensation and a compartmental approach to common law assessments. The latter tends to be more focussed in defining the remedial goal pursued, whether that be punishment, restoration of the plaintiff to its original position, or protection of expectation. Equitable compensation lacks that clarity. Before embarking on the equitable compensation project it is apt to reflect on the common law development and the rationale for its principles of assessment. For instance the concept of remoteness reflects the philosophy that a person should not be exposed to an indeterminate amount of liability to an indeterminate class of individuals, and that, generally speaking, a person should only beheld liable for that which he or she can control. The concept also reflects the practical necessity to standardise damage assessment against subjective valuations of either judge or jury. Again, equitable compensation as conceived by the Supreme Court of Canada currently lacks these refinements and is unclear on its philosophical underpinnings of damage assessment.

A final point concerns the Court's approach to remedying equitable wrongs. The conclusion that infringement of confidentiality was purely an equitable right and that no common law right existed necessitated the discussion on equitable compensation in Cadbury Schweppes Inc. Yet, the judgment is wider than this and suggests that equitable compensation is available for infringementof any equitableright. Does this mean that equitable compensation can now be paid for breach of an equitable right arising in exercise of equity's auxiliary jurisdiction as well as in exercise of its substantive or original jurisdiction? Two examples spring to mind. Currently a third party, particularly banks, given notice of a Mareva injunction

132 See Hodgkinson $v$ Simms [1994] 3 SCR 377.

133 L Fuller and W Perdue "The Reliance Interest in Contract Damages" (1936) 46 Yale LJ 52. 
are bound to obey it on pain of being held liable for contempt of court. Contempt of court is a singularly blunt weapon and does little to assist the plaintiff once the order has been breached. Is it now possible to argue for equitable compensation as a remedy for breach of the Mareva injunction by the third party? Similarly, a person seeking rectification loses that right where a third party has intervened. Could the plaintiff now seek equitable compensation where rectification would have been granted but for the presence of the third party? 
